TRENDS IN REGIONAL INDUSTRIAL CONCENTRATION IN THE UNITED STATES

\author{
by \\ Joshua Drucker * \\ University of Illinois at Chicago
}

CES 09-06 April, 2009

The research program of the Center for Economic Studies (CES) produces a wide range of economic analyses to improve the statistical programs of the U.S. Census Bureau. Many of these analyses take the form of CES research papers. The papers have not undergone the review accorded Census Bureau publications and no endorsement should be inferred. Any opinions and conclusions expressed herein are those of the author(s) and do not necessarily represent the views of the U.S. Census Bureau. All results have been reviewed to ensure that no confidential information is disclosed. Republication in whole or part must be cleared with the authors.

To obtain information about the series, see www.ces.census.gov or contact Cheryl Grim, Editor, Discussion Papers, U.S. Census Bureau, Center for Economic Studies 2K130B, 4600 Silver Hill Road, Washington, DC 20233, Cheryl.Ann.Grim@census.gov. 


\begin{abstract}
In a seminal article, Benjamin Chinitz (1961) raises the question of the effects that industry size, structure, and economic diversification may have on firm performance and regional economies. His line of inquiry suggests a related but conceptually distinct issue: how does the extent to which a industry is regionally dominated-concentrated locally in a single or small number of firms - impact the local performance of that industry? This question has received little attention, principally because accurately measuring industrial concentration at the regional scale requires firm-level information. This paper makes use of confidential plant- and firm-level manufacturing data to explore patterns of industrial concentration in the United States at the regional scale. Regional analogues of concentration ratios and other measures commonly used in the aspatial industrial organization literature indicate the extent to which manufacturing activity is concentrated in a small number of firms. Both the manufacturing sector as a whole and major manufacturing industry sectors are examined in order to determine the extent of industrial concentration in the continental United States, to explore changes over time in geographic patterns of concentration, and to investigate associations between industrial concentration and employment growth at the regional scale. Implications for understanding regional growth and for devising regional economic development policy are discussed.
\end{abstract}

* This work has been supported by awards from the National Science Foundation (grant NSF-BCS 0423900), the Ewing Marion Kauffman Foundation, and the North American Regional Science Council. Additional support for the Triangle Census Research Data Center comes from the National Science Foundation (grants NSF-SES 0004322 and NSF-ITR 0427889). Part of the research was conducted while the author was a Special Sworn Status researcher of the United States Census Bureau at the Triangle Census Research Data Center. The contents of this study have been screened to ensure that no confidential data are revealed. All contents and conclusions expressed are solely the responsibility of the author and do not necessarily reflect the views of any of the supporting organizations or the United States Census Bureau. 


\section{Trends in Regional Industrial Concentration in the United States}

\section{INTRODUCTION}

In a seminal article in The American Economic Review in 1961, Benjamin Chinitz describes possible linkages between the structure of a region's economy and its capacity to adapt continually to changing economic conditions and to regenerate itself over time. Chinitz discusses several possible facets of regional economic structure, among them the absolute size of regional industries, the extent of sectoral diversity in the regional economy, and the degree to which one or a few large firms dominate the regional mix of businesses. Subsequent researchers have investigated Chinitz' hypotheses about the relationship between regional industrial structure and economic development by measuring structure with indicators of overall industry size (often conceptualized as a localization economy effect) and sectoral diversity. The particular question of whether the domination of an industry by a few companies in a locality influences the performance of the other business enterprises in the same regional industry — particularly those that are small or entrepreneurial — has been largely overlooked, principally because the accurate measurement of industrial concentration at the regional scale requires firm-level information. Multiple establishments of varying sizes in a given locality may be part of the same firm. Therefore, commonly used secondary data sources on establishment size distributions in the United States (e.g., from County Business Patterns or published data from the Census of Manufactures) can offer only an incomplete picture of the true level of corporate dominance in a region.

This paper uses a confidential establishment-level manufacturing dataset compiled by the United States Census Bureau, the Longitudinal Research Database, to explore current and historical patterns of industrial concentration at the regional scale in the United States. For a given region and manufacturing industry, establishments are aggregated into firms and then several measures of industrial dominance are calculated, including the ratio of employment in the largest regional firms to total regional employment in the industry. These measures of industrial dominance are regional analogues to concentration ratios and other concentration measures commonly used in the aspatial industrial organization literature (Pryor 2001). The paper describes the extent to which manufacturing activity is concentrated in a small number of large 
firms at the regional level, examines variations in manufacturing concentration across regions of the continental United States and changes in those geographic patterns over time, and explores the associations between regional industrial concentration and employment growth.

The link between regional industrial dominance and economic performance has important implications for economic development planning given ongoing industrial restructuring and associated workforce dislocation in the U.S., as well as continuing trends toward offshoring both labor- and technology-intensive economic activity. Industrial dominance is a specific mechanism by which regions may "lock in" to a particular set of industrial competencies. As markets evolve and technology changes, those competencies, once key economic engines, eventually may become economic liabilities (Bergman 2002). This notion is illustrated perfectly by the case Chinitz highlighted in his original paper: steel manufacturing in the metropolitan Pittsburgh region. Pittsburgh eventually remade its economy around the medical and information technology sectors, but not without a wrenching transition that required the breakdown of institutional structures "hardened" around the steel industry and dominant steel companies (Flammang 1990). Smaller regions, in particular "one-company towns," are especially vulnerable to such dynamics, as they often are faced with the challenge of remaking themselves entirely in the face of heightened global competition.

This study follows earlier research that uses a productivity framework to link regional industrial dominance in several U.S. manufacturing industries to diminished economic performance at the plant level (Drucker 2007; Drucker and Feser 2007). The demonstrated impact of dominance in reducing the productivity of small and medium-sized manufacturing establishments provides motivation for a broader exploration of the phenomenon of regional industrial dominance throughout the U.S. manufacturing sector. The paper also forms part of a larger research project that employs a range of research design strategies, including econometric modeling and case study investigations, to examine different aspects of regional industrial dominance. This work presents an exploratory analysis, measuring and documenting trends in the extent of regional industrial concentration in an effort to establish a new and valuable line of inquiry for economic development planning researchers.

The next section of the paper provides a brief review of previous research that pertains to the topic of regional industrial dominance. The subsequent segment details the data sources and defines the variables and measures used, focusing on the operationalization of the regional 
industrial dominance concept. The empirical analysis is separated into three parts. The first portion examines historic trends in dominance across U.S. regions over time. The second section explores associations between dominance and employment growth in the manufacturing sector, and the third extends the approach by disaggregating the manufacturing sector into component industry categories. The paper concludes by summarizing the findings and discussing implications for policy and research.

\section{PREVIOUS WORK}

Little work has aimed directly at the particular topic of industrial dominance at the regional scale. Researchers interested in the questions raised by Chinitz concerning the influence of industrial structure at the regional level have focused mainly on the regional characteristics of industrial or sectoral diversity, average establishment size, and industry scale. In fact, a debate in the literature argues over which of these traits best corresponds to the ideas put forth by Chinitz (e.g., Evans 1986; Carlino 1987; Norton 1992), eventually conceding that each offers a useful but partial representation of regional industrial structure.

A wide variety of empirical studies, examining settings both within and outside the United States and across a substantial scope of time, demonstrate that a greater degree of regional industrial diversity generally supports a number of desirable outcomes. These outcomes include employment growth, the formation of new firms, rising wages, patenting activity, regional economic stability, greater transfer of beneficial spillovers, and growth in productivity and population at the city and regional levels (Thompson 1974; Blair 1975; Scherer 1980; Begovic 1992; Friedman 1995; Henderson et al. 1995; Bostic et al. 1997; Quigley 1998; Holmes 1999; Hanson 2001; Armington and Acs 2002; Capello 2002; Audretsch 2003; Henderson 2003; Rosenthal and Strange 2004). Many researchers have found that rates of unemployment and other indicators of regional employment instability tend to be moderated by heterogeneity in regional industrial composition (among them are Conroy 1975; Brewer 1985; Garcia-Mila and McGuire 1993; Malizia and Ke 1993; Hunt and Sheesley 1994; Wagner and Deller 1998; Mizuno et al. 2006; Trendle 2006; see Dissart 2003 for a review). Glaeser et al. (1992) and Feldman and Audretsch (1999) demonstrate that employment growth and the introduction of innovations, respectively, are supported by local industrial diversity in the United States. 
Furthermore, unemployment rates are lower and per capita personal income tends to be higher in U.S. states with greater industrial diversity (Izraeli and Murphy 2003). Similar relationships hold in other industrialized nations around the globe. For example, Combes (2000) finds greater diversity supportive of employment growth in France, Chen (2002) reports that employment and wage growth are positively related to diversity in Taiwanese cities, and Andersson et al. (2005) reveal that a diverse regional employment base in Sweden is associated with higher patenting rates.

Similar to the findings regarding industrial diversity, at the regional industry level, smaller average firm or plant size is positively related to a broad range of advantageous outcomes, such as the availability of suppliers and qualified labor, the introduction of innovations, the capture of knowledge spillovers, technology adoption, entrepreneurial start-up activity, firm growth, and productive efficiency (Blair 1978; Acs and Audretsch 1990; Keeble and Walker 1994; Audretsch 1995; Harrison et al. 1996; Fritsch and Lukas 1999; Kelley and Helper 1999; Fritsch and Meschede 2001; Chevassus-Lozza and Galliano 2003). For instance, in regional European industries, smaller shares of total employment in large firms result in greater value added (Carree and Thurik 1999). Combes (2000) reports that larger average plant size detracts from regional employment growth in French manufacturing and service industries, and Nystrom (2007) finds that greater average plant size dampens the rate of firm births as well as deaths in Sweden. In the United States, average establishment size is negatively related to firm births (Armington and Acs 2002; Acs and Armington 2004a; Lee et al. 2004), household income (Shaffer 2002; 2006a), and employment growth (Shaffer 2006b; Loveridge and Nizalov 2007). There are some contrary indications as well. According to Acs and Armington (2004b), greater average establishment size is associated with faster regional employment growth across the United States. In Texas, mean establishment size is positively related to new firm formation rates (Sutaria and Hicks 2004). Finally, an exploratory study by Kim (1995) provides a methodological as well as substantive antecedent for this research. He describes long-run trends in manufacturing specialization across U.S. regions, and explores the relationship between the specialization of regions and the localization of manufacturing industries. Kim also measures a positive association between industrial localization and average plant size, consistent with the implication of scale economies in production, a result verified by subsequent research (Holmes and Stevens 2002; Barrios et al. 2006; Wheeler 2006; Lafourcade and Mion 2007). 
A large and diverse body of work illuminates a different facet of local industrial structure by focusing on the relationship between overall industry size or density (relative concentration within the local economy) and economic performance. Although the quantitative methodologies employed vary widely, these studies typically are rooted in the agglomeration economies literature, with the scale of an industry or its regional density conceptualized as an indicator of localization economies. Such localization advantages benefit productivity, profitability, employment growth, and innovation performance, encourage firm births, and attract firms making location choices. Examples include Shefer (1973), Henderson (1986), Moomaw (1986), Henderson et al. (1995), Henderson (1997), Feser (2001), Gabe (2003), Crozet et al. (2004), Desmet and Fafchamps (2005), Audretsch and Dohse (2007), Fritsch and Falck (2007), and Kambhampati and McCann (2007).

Although the literature examining industry scale, industrial diversity, and average plant size yields useful information and insights, the concepts are not adequate to represent the phenomenon of regional industrial dominance. The scale or size of an industry in a region, though empirically associated with dominance (see below), is a feature distinct from the internal structure. Moreover, industry scale does not directly lead to observed impacts on economic performance, but rather proxies other phenomena. Industry size may confer opportunities for resource pooling or knowledge spillovers, reducing production costs in either the short or long run, or agglomeration economies may alter the optimal firm organizational structure, enabling greater specialization and efficiency. Similarly, industrial diversity pertains to sectoral mix (the combination of economic activities in a region) rather than industrial structure directly, and average establishment size indicates the degree of industrial concentration or dominance within a region only in an aggregate fashion. Regional industrial dominance may have separate implications that are important for understanding the economic dynamics of the vast majority of regions that neither experience overriding economic dominance by a single firm or industry nor possess approximately competitive markets in each industry.

One of the reasons that most researchers have focused on industrial diversity and industry or establishment size as indicators of industrial structure is the lack of suitable publicly accessible data at the establishment or firm level. A second reason is that it is difficult to examine the implications of concentration for a single industry directly because of the need to distinguish the effects of industrial structure from other industry-specific influences on 
performance (Gort and Sung 1999). Two empirical studies come relatively close to the dominance concept by investigating the relative distribution of firm sizes within industries. Acs et al. (1999) find that industries in which employment is more highly concentrated in large firms at the national level tend to have greater productivity growth, though they acknowledge that the effect could be due to survival bias. Rosenthal and Strange (2003) use Dun \& Bradstreet's MarketPlace database to calculate indicators of corporate structure at the regional level, along with industrial diversity and concentric ring measures of localization and urbanization economies, for six industries. They report that a higher concentration of regional industry employment in smaller establishments (which they describe as an "entrepreneurial industrial system") is associated with more firm births and new-establishment employment.

Turning to the field of industrial organization, empirical research on Gibrat's Law would seem to hold some promise for informing the question of regional dominance. Gibrat's Law is the proposition that firm growth rates are independent of the firm size already attained. It was suggested initially in order to explain the skewed shape regularly found in the distribution of firm sizes (for reviews, see Sutton 1997; Caves 1998; Audretsch et al. 2004). Most of the research on the topic, however, fails to consider location as a relevant factor and emphasizes idiosyncratic or sector-specific factors behind observed industry differences (Schmalensee 1989; Davies and Geroski 1997). Furthermore, empirical investigation is limited by a methodological approach - the matching of precisely defined distributions to empirical phenomena - that sets up "extreme" hypotheses that cannot be evaluated with standard inferential statistics (Ijiri and Simon 1977; Powell 2003).

Measuring firm size distributions with simple indicators rather than fitting fully defined distributions provides a strategy for avoiding the problems of extreme hypotheses (Needham 1978; Hay and Morris 1991). Summary statistics are regularly substituted for the full specification of the firm size distribution in industrial organization studies (examples include Martin 1979; Shepherd 1982; Attaran and Saghafi 1988; Kambhampati 1998; Robinson and McDougall 1998; Robinson 1999; Kelly and Gosman 2000; Pryor 2001; Bottazzi et al. 2007). One complication is that there are numerous possible indicators possessing different properties, with no general agreement upon which are the best or most useful (Amato 1995). Measures of concentration based on size traits such as employment or sales have been examined extensively in relation to industry-level profit rates, with recent studies suggesting that firms in less 
concentrated industries may earn higher profit rates controlling for market share (Schmalensee 1989; Amato and Wilder 1995; Azzam et al. 1996; Cool and Henderson 1998; Fourie and Smith 1998; 1999). Empirical studies in several nations suggest that industrial concentration can affect performance negatively or positively, depending on the level of concentration (Caves and Barton 1990; Porter 1990; Nickell 1996; Nickell et al. 1997; Gort and Sung 1999; Gumbau-Albert and Maudos 2002; Gopinath et al. 2004). Industrial concentration also has been linked to changes in productivity over time and innovation intensity (Scherer 1967; 1980; Cohen and Levin 1989; Nickell 1996; Nickell et al. 1997; Cortes 1998; Vossen 1999; Bhattacharya and Bloch 2004; Rogers 2004; Melville et al. 2007).

To summarize, most of the empirical research following Chinitz in investigating the implications of regional industrial scale and structure examines characteristics other than regional industrial dominance. Two previous studies that begin to explore industrial concentration by investigating the partition of industry employment by firm size categories reach opposite conclusions, though at contrasting spatial scales and with regard to different outcome measures. The topic of industrial concentration has received attention in the industrial organization literature, but either at a greater-than-regional scale or in an entirely aspatial manner. As a practical consideration, the difficulties encountered in attempting to fit fullyspecified firm size distributions encourage the utilization of summary indicators for this research.

\section{MEASURING DOMINANCE}

Plant-Level Data Source. The accurate measurement of regional industrial dominancethe extent to which an industry or sector in a region is concentrated in one or a small number of large firms - requires information concerning individual establishments or firms. The primary data source for this study is the Longitudinal Research Database (LRD) of the United States Census Bureau. ${ }^{1}$ The LRD is compiled from confidential establishment-level records collected for the quinquennial Census of Manufactures (CM) and the Annual Survey of Manufactures (ASM) and is housed at the Center for Economic Studies. ${ }^{2}$ The coverage starts in 1963 and at

\footnotetext{
${ }^{1}$ See McGuckin and Pascoe (1988) and McGuckin (1990) for details of the construction and contents of the LRD.

2 The Census of Manufactures is collected in years ending in " 2 " and " 7 ", with the exception of the first year of collection in 1963. The Annual Survey of Manufactures is conducted in the remaining four out of every five years.
} 
present stretches to the 2002 Census and the 2005 Survey. ${ }^{3}$ The LRD contains detailed longitudinal information on establishment locations (counties), industry classification, and other establishment characteristics for nearly all manufacturing plants across the United States.

Although the LRD includes information on all establishments in the United States reporting under a manufacturing industry code, the coverage is less complete for small establishments in non-census years. The ASM is a five-year panel sample of plants with rotating membership. ${ }^{4}$ Only large plants (normally those with at least 250 employees) are included with certainty in each ASM; the remainder of the sample is selected randomly to reduce data gathering costs and reporting burdens, with the probability of selection inversely related to establishment size. ${ }^{5}$ Sample weights support imputations to national industries or to entire manufacturing sectors, but not to industries at the regional scale. In any given year the ASM includes less than 20 percent of manufacturing plants in the United States. Since this study focuses on the distributions of large and small establishments, only data from CM years of the LRD are used in order to obtain the most accurate balance among establishment sizes.

Establishments reporting zero employment are excluded from the analysis.

The nine available census years of the LRD are included in this analysis: 1963, 1967, $1972,1977,1982,1987,1992,1997$, and 2002. Caution has to be exercised in using the data from some of these years. Firstly, the 1963 and 1967 datasets contain irregularities in certain locations that are not rectifiable from original census documents. ${ }^{6}$ Although the abnormalities are relatively small and therefore should not have major implications for the examination of trends spanning multiple years and states, the reliability of analytical results pertaining to those years is not certain. Secondly, starting with the 2002 Census of Manufactures, plants are categorized into industries according to the North American Industrial Classification System (NAICS) rather than the older Standard Industrial Classification (SIC) system. At the aggregate manufacturing sector level, the practical consequence is that changes in the set of activities that are considered to constitute manufacturing must be taken into account. ${ }^{7}$ For specific

\footnotetext{
${ }^{3}$ Annual coverage begins in 1972 since the first year of the ASM is 1973.

${ }^{4}$ Each ASM panel is surveyed the two years prior to and the two years subsequent to a census year.

${ }^{5}$ Prior to 1979, the unit determining selection was the firm rather than the establishment (Davis et al. 1996).

${ }^{6}$ It is known that there are irregularities in establishment counts and employment totals in portions of Florida, North Carolina, Virginia, and Wisconsin. It is possible that there are additional undiscovered errors pertaining to other locations.

${ }^{7}$ As an example, manufacturing headquarters are classified within manufacturing in the SIC system, but in a separate category titled Management of Companies and Enterprises in NAICS.
} 
manufacturing industries, the industry definition modifications make it difficult to conduct meaningful longitudinal analysis across the break. Therefore, the exploratory regressions in second portion of the analysis focus on the most recent decade of data available prior to the classification switch, covering from 1987 to 1997.

Because the LRD is compiled from confidential records, the use of the dataset and the release of descriptive statistics and results obtained from its analysis are strictly regulated. All of the information contained within this document has been reviewed by Census Bureau staff to ensure that no confidential data are revealed either directly or in possible combination with other publicly available information. The confidentiality restrictions and disclosure screening requirements limit the types and quantity of information possible to extract for this study. Therefore, in some places qualitative descriptions take the place of numerical tabulations or other quantitative information, and some potentially interesting but nonessential results are omitted.

Regions. Metropolitan Statistical Areas (MSAs) are appropriate units for examining regional industrial interactions because they approximate functional economic areas across which industrial dominance may be expected to influence interfirm interactions. This study adopts the 1999 MSA and Consolidated Metropolitan Statistical Area (CMSA) definitions prepared by the United States Census Bureau (2002). ${ }^{8}$ Although metropolitan definitions have changed over time, it is necessary to use a single consistent set for the longitudinal analyses. In using designations from a recent year, the study errs on the side of inclusivity. The 1999 MSAs include some counties that in earlier decades had little interaction with the central portions of metropolitan regions; such relatively small and rural counties would not be expected to affect the analytical outcomes too extensively. The alternative choice of boundary designations from an earlier year would introduce more serious distortions by excluding counties that have since become substantial and functionally integrated components of metropolitan areas. Regions in Alaska and Hawaii are omitted due to their relatively isolated locations. It should be noted that non-metropolitan areas are not included in the study. ${ }^{9}$

Regional Industrial Dominance Measures. The operationalization of industrial dominance at the regional scale is key to this study, but as the concept has not appeared in

\footnotetext{
${ }^{8}$ Results obtained using Primary Metropolitan Statistical Areas (PMSAs) instead of CMSAs are substantively equivalent.

9 The concept of intra-industry dominance is not applicable to most rural areas where low firm densities rule out the importance of spatially-bounded interfirm interactions.
} 
quantitative empirical research, there is no strong theoretical or empirical basis upon which to base the selection of an appropriate measure. Earlier work conducted at the industry scale has adopted indicators for industrial concentration or market power based on a variety of different summary measures, including concentration ratios, likelihood ratios, the Gini coefficient, the Herfindahl-Hirschman index, entropy measures, and the sample variance of firm size (Hay and Morris 1991; Powell 2003; Powell and Lloyd 2005). Empirical comparisons demonstrate that no single measure is superior to the others (Hay and Morris 1991; Amato 1995). This study considers five different indicators of regional industrial dominance.

Concentration ratios are probably the most widely used type of measure, partly because they are available from the United States Census Bureau at the national level in public-release versions of the Census of Manufactures (Golan et al. 1996). For this research, the concentration ratio carries the advantage that it is relatively insensitive to the pattern of firm sizes that occurs at the low end of the distribution, which accords with the conception of dominance as the degree to which an industry is concentrated into a few large firms. Therefore, a five-firm concentration ratio is adopted as the principal measure of regional industrial dominance. Establishments are first aggregated to the level of firms based on the same-industry same-region manufacturing components of multi-unit firms. Then the concentration ratio measure is simply the ratio of employment in the five largest "dominator" firms to total regional employment in the industry. Because regional industrial dominance is only a meaningful concept in situations in which "dominant" companies can be distinguished from a larger set of non-dominant firms, only regions containing at least twelve firms in the industry are included. ${ }^{10}$

Industrial concentration or market power is also measured with indices that are constructed from the full set of firm size shares. Some industrial economists contend that these indices are preferable to concentration ratios precisely because they do take into account the entire firm size distribution and thus are sensitive to both the total number of firms and the relative distribution of size among firms; concentration ratios essentially depend on only one point in the size distribution (Hay and Morris 1991; Amato 1995). The indices are distinguished

\footnotetext{
${ }^{10}$ Numerous variations of this dominance measure were tested, varying the number of firms contained in the numerator of the concentration ratio, altering the minimum number of firms in the regional industry for inclusion, substituting shipment value for employment, and calculating a plant-based rather than a firm-based ratio. The results obtained with the alternative measures are qualitatively similar, though the performance of the five-firm employment-based concentration ratio generally is superior in terms of consistency and statistical strength of results. Due to disclosure restrictions, the alternative results are not discussed further.
} 
by the particular scheme for weighting the firm size shares. Three are utilized in this study. The most common is the Herfindahl-Hirschman index, which weights each size share proportionally to relative firm size by summing the squares of each firm's share of regional industry employment. Because the weights emphasize the largest firms, the index is quite insensitive to the size distribution among the smaller firms. Theil's entropy measure is similar to the Herfindahl-Hirschman index, but uses the natural logarithm of the size shares instead of the unadjusted size shares as weights, reducing to a degree the emphasis placed on the largest firms (Attaran and Saghafi 1988). The Rosenbluth index instead weights by descending firm size rank. By weighting the smallest firms the most heavily, the Rosenbluth index stresses the small end of the firm size distribution. Unlike the concentration ratio, these three indices can be calculated for regional industries with any number of firms. Nevertheless, the same minimum of twelve firms in the industry is imposed to preserve the meaningfulness of the intra-industry regional dominance concept, and also to maintain identical estimation samples across the different dominance measures.

Finally, the Gini coefficient is included as a relative concentration measure. The concentration ratio, the Herfindahl-Hirschman index, Theil's entropy measure, and the Rosenbluth index are all absolute in the sense that they depend in some manner on the total number of observations. In contrast, the Gini coefficient is independent of the number of firms in a regional industry. The Gini coefficient may be measured by the area under a Lorenz curve, visually indicating the extent to which the size distribution differs from equal apportionment, or may be calculated more simply via the fact that it is the relative counterpart of the Rosenbluth index (Needham 1978). The Gini coefficient is often interpreted as an indicator of the degree of inequality in a distribution. As with the other dominance measures, the Gini coefficient is only considered for those regional industries with a minimum of twelve firms.

Table 1 lists the five dominance measures considered in the analysis, their calculation formulae, and their theoretical ranges. ${ }^{11}$ Except for Theil's entropy measure, larger values of each of the indices reflect greater degrees of regional industrial dominance. Theil's entropy is

\footnotetext{
${ }^{11}$ As with the concentration ratio measure, versions of the four alternative measures were tested altering the flexible parameters: the exponent in the Herfindahl-Hirschman formula, the minimum number of regional industry firms for sample inclusion, and substituting shipment value for employment as the size variable. The conclusions presented in this paper are qualitatively robust to these alternative specifications.
} 
Table 1. Measures of Regional Industrial Dominance.

\begin{tabular}{|c|c|c|c|c|c|}
\hline \multicolumn{2}{|c|}{ Measure } & \multirow{3}{*}{$\begin{array}{l}\text { Description } \\
\text { sum of size shares of } \\
\text { five largest firms }\end{array}$} & \multirow{3}{*}{$\begin{array}{l}\text { Formula } \\
\qquad \frac{\sum_{i=1}^{5} E_{i}}{\sum_{i} E_{i}}\end{array}$} & \multicolumn{2}{|c|}{ Dominance Range } \\
\hline & & & & $\min$. & $\max$ \\
\hline$D_{C}$ & $\begin{array}{l}\text { Five-firm } \\
\text { concentration ratio }\end{array}$ & & & $5 / n$ & 1 \\
\hline$D_{H}$ & $\begin{array}{l}\text { Herfindahl- } \\
\text { Hirschman index }\end{array}$ & $\begin{array}{l}\text { sum of squared firm size } \\
\text { shares }\end{array}$ & $\sum_{i}\left(\frac{E_{i}}{\sum_{i} E_{i}}\right)^{2}$ & $1 / n$ & 1 \\
\hline$D_{E}$ & Theil's entropy & $\begin{array}{l}\text { sum of firm size shares } \\
\text { weighted by natural log } \\
\text { of firm size }\end{array}$ & $\sum_{i} \frac{E_{i}\left(-\ln E_{i}\right)}{\sum_{i} E_{i}}$ & $\ln (n)$ & 0 \\
\hline$D_{R}$ & Rosenbluth index & $\begin{array}{l}\text { sum of firm size shares } \\
\text { weighted by descending } \\
\text { size rank }\end{array}$ & $2 \sum_{i}\left(i \cdot \frac{E_{i}}{\sum_{i} E_{i}}\right)-1$ & $1 / n$ & 1 \\
\hline$D_{G}$ & Gini coefficient & $\begin{array}{l}\text { difference from equal } \\
\text { distribution }\end{array}$ & $1-\frac{1}{n \cdot D_{R}}$ & 0 & $1-1 / n$ \\
\hline
\end{tabular}

Note: $n$ is the number of firms in the regional industry, $i$ indexes the firms in the regional industry in descending size order, and $E_{i}$ represents the employment of the $i^{\text {th }}$ firm.

reversed in that larger values indicate less dominance; the more closely the measure approaches zero, the greater the degree of dominance.

\section{HISTORIC TRENDS IN MANUFACTURING DOMINANCE}

Table 2 reports the extent of regional industrial dominance across the manufacturing sector. The five indicators of dominance are calculated for each of the 275 MSAs and CMSAs in the continental United States, with each region constituting a single observation. Table 2 presents basic descriptive statistics — mean and standard deviation-across these 275 observations for each Census of Manufactures year of the LRD. Figure 1 separates the shifts over time in dominance from the scales of the individual measures by displaying the means of each indicator normalized to their 1972 values. 
Table 2. Regional Industrial Dominance in Manufacturing.

\begin{tabular}{lcccccccccc} 
Year & & 1963 & 1967 & 1972 & 1977 & 1982 & 1987 & 1992 & 1997 & 2002 \\
\hline $\begin{array}{l}\text { Dominance } \\
\text { Concentration Ratio } \\
\left(\mathrm{D}_{\mathrm{C}}\right)\end{array}$ & mean & 0.4621 & 0.4686 & 0.4428 & 0.4228 & 0.4108 & 0.3940 & 0.3829 & 0.3610 & 0.3697 \\
& std dev. & 0.1821 & 0.1843 & 0.1796 & 0.1770 & 0.1758 & 0.1716 & 0.1725 & 0.1707 & 0.1753 \\
$\begin{array}{c}\text { Herfindahl-Hirschman } \\
\left(\mathrm{D}_{\mathrm{H}}\right)\end{array}$ & mean & 0.0944 & 0.0933 & 0.0825 & 0.0781 & 0.0757 & 0.0680 & 0.0654 & 0.0574 & 0.0604 \\
Theil's Entropy & std dev. & 0.0971 & 0.0884 & 0.0782 & 0.0771 & 0.0802 & 0.0699 & 0.0717 & 0.0630 & 0.0710 \\
$\left(\mathrm{D}_{\mathrm{E}}\right)$ & mean & 3.7065 & 3.6689 & 3.8100 & 3.9016 & 4.0202 & 4.1223 & 4.1941 & 4.3080 & 4.2590 \\
Rosenbluth & std dev. & 1.1133 & 1.1073 & 1.1215 & 1.1296 & 1.1478 & 1.1461 & 1.1722 & 1.1823 & 1.1940 \\
$\left(\mathrm{D}_{\mathrm{R}}\right)$ & mean & 0.0399 & 0.0429 & 0.0375 & 0.0339 & 0.0298 & 0.0276 & 0.0264 & 0.0240 & 0.0257 \\
Gini & std dev. & 0.0397 & 0.0402 & 0.0336 & 0.0297 & 0.0277 & 0.0270 & 0.0270 & 0.0244 & 0.0260 \\
$\left(\mathrm{D}_{\mathrm{G}}\right)$ & mean & 0.7963 & 0.8177 & 0.8096 & 0.8131 & 0.8010 & 0.7961 & 0.7987 & 0.8010 & 0.8076 \\
\hline
\end{tabular}

Note: There are 275 MSA and CMSA observations per year.

Figure 1. Trends in Regional Industrial Dominance.

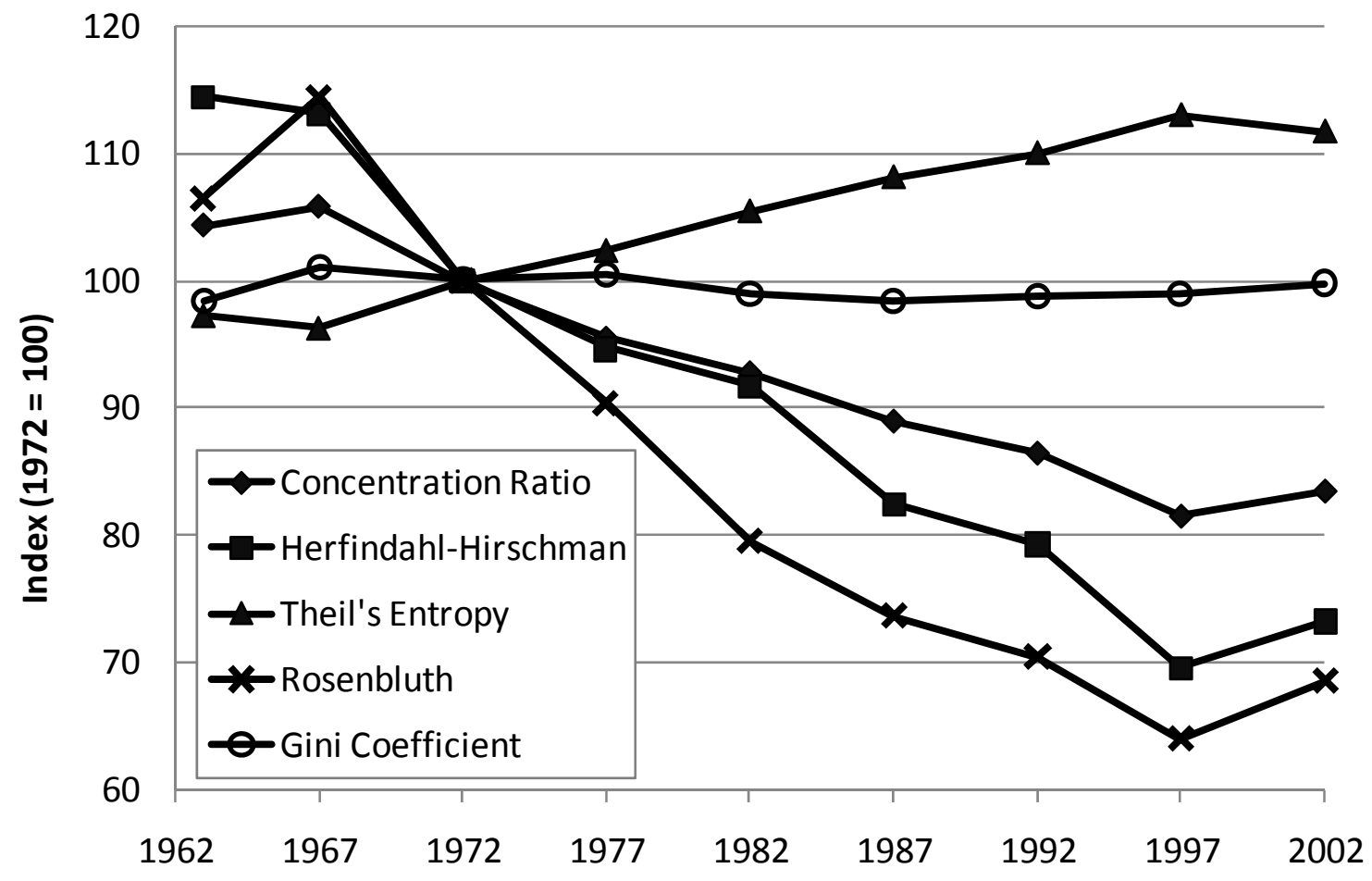


Regional dominance in manufacturing has been declining over time. The mean values of the four absolute dominance measures (concentration ratio, Herfindahl-Hirschman index, Theil's entropy, and Rosenbluth index) have moved steadily in the direction of less dominance from 1967 through 1997. (Recall that larger values of Theil's entropy measure signify lower levels of dominance.) The standard deviations of the indicators have also declined over the past four decades, but to a degree that coincides with the smaller indicator magnitudes (Table 2). ${ }^{12}$ The concentration ratio and Theil's entropy measures show between a ten and twenty percent decline in the mean measure of regional manufacturing dominance between 1972 and 1997 (Figure 1). The Herfindahl-Hirschman and Rosenbluth indices reveal larger drops. The rise in dominance in 2002 may signal a shift in the long-term direction or a one-period exception to the persistent trend, or may be instead an artifact of the change in industry classification system.

The most straightforward explanation for the observed reduction in manufacturing dominance at the regional scale over time is that the largest companies are not maintaining their size advantage over smaller manufacturing firms. This could be due to several numerical scenarios, such as greater employment growth in smaller firms, employment stability in the largest firms combined with increasing entry at the small end of the firm size scale, or the largest firms declining in size or exiting the industry. Given the national trends of diminishing manufacturing employment and average plant sizes, however, and fewer establishments as well more recently (see Table 3 ), the reduction in dominance is most likely caused by greater-thanproportional employment declines in larger manufacturing firms.

Vertical disintegration of production may one factor behind the declines in dominance and average plant size in the manufacturing sector. As large firms outsource portions of the manufacturing process, employment shifts from sizable enterprises to smaller intermediate suppliers (located either within or outside the region) and to establishments classified in nonmanufacturing industries, particularly business and professional services. Evidence of "hollowing out"-regional manufacturing industries becoming increasingly specialized in particular portions of product chains and decreasingly dependent on locally manufactured intermediate inputs-reinforces this explanation (Hewings et al. 1998; Okuyama et al. 2006).

\footnotetext{
12 The standard deviation of the Theil's entropy measure has increased as the numerical value of that indicator has risen.
} 
Table 3. United States Manufacturing Sector Trends.

\begin{tabular}{crrc} 
Year & Establishments & Employment & Average Employment \\
\hline 1977 & 327,850 & $19,638,852$ & 60 \\
1982 & 328,932 & $19,572,113$ & 60 \\
1987 & 371,018 & $19,002,692$ & 51 \\
1992 & 386,629 & $18,162,480$ & 47 \\
1997 & 393,091 & $18,632,696$ & 47 \\
$2002^{*}$ & 344,341 & $14,393,609$ & 42 \\
$2005^{*}$ & 333,460 & $13,667,337$ & 41 \\
\hline
\end{tabular}

* 2002 and 2005 reflect switch to from NAICS to SIC.

Source: County Business Patterns (United States Census Bureau, n.d.).

One reason to examine multiple indicators of dominance is to reduce the possibility that observed trends are due to unique traits or idiosyncrasies of a particular summary statistic. Because the concentration ratio principally reflects the status of the largest firms, it could be misleading in situations in which the total number of firms is changing rapidly. For instance, a rapid rise in the number of small manufacturing firms and stable employment levels in large companies would lead to only small declines in the five-firm concentration ratio calculated across the entire national manufacturing industry, but would be reflected in much greater drops in the Herfindahl-Hirschman index and especially the Rosenbluth index. Indeed, the Rosenbluth index, which emphasizes the small end of the firm size distribution, evidences the greatest percentage declines in dominance, and the concentration ratio among the least (Figure 1).

The Gini coefficient reveals a different pattern, holding relatively steady across the nine CM years. The Gini coefficient exhibits less variation across regions as well as over time, with standard deviations only a small fraction of the mean index value (Table 2). This suggests a more complex dynamic at work. If the number of manufacturing firms were constant over time, then greater-than-proportional employment declines in larger firms would tend to lower the Gini coefficient, indicating greater size equality. One possibility is that large employment declines in sizable manufacturing companies are being accompanied by greater net exit rates at the small end of the size distribution, keeping the level of inequality as indicated by the Gini coefficient roughly constant while driving down regional manufacturing dominance in absolute terms. This 
explanation is consistent with the "hollowing out" phenomenon and declines in regional manufacturing industries supplying intermediate inputs.

Figure 2 disaggregates the trend in the concentration ratio measure of dominance by Census division (see Appendix Figure A1 for Census region and division definitions and Appendix Table A1 for the numerical figures underlying Figure 2). ${ }^{13}$ Census divisions within the same Census region are assigned identical line patterns but distinct marker shapes. All of the nine Census divisions exhibit the decline in regional manufacturing dominance over time that is evident in Figure 1 for the nation as a whole. Although there are occasional upticks in the concentration ratio in particular Census divisions, the general trend is toward lower levels of regional industrial dominance in each region, with the possible exception of the West South Central division since 1982.

The rank order of the Census divisions in terms of the average degree of regional manufacturing dominance has remained stable, but the average levels have converged over the four decades examined. The West North Central and Mountain divisions demonstrate the greatest average dominance levels, and the coastal Middle Atlantic and Pacific divisions - the areas of the nation with the greatest levels of innovation and new business formation over the long term-evidence the lowest degrees of manufacturing dominance. The rapid decline in dominance in the Mountain division contrasts with the relatively constant level of manufacturing dominance in New England, the nation's oldest manufacturing region. Except for the West region, the Census divisions within each region display patterns closely similar to each other, with mean levels of dominance increasing from the Northeast through the Southeast to the Midwest. In the West, the Pacific division has consistently low and the Mountain division high levels of regional manufacturing dominance. The evidence of consistency in relative order and convergence over time in average levels of dominance across the subnational regions suggests that declines in manufacturing dominance may reflect the position each region occupies with respect to ongoing processes of maturation and transformation occurring within the manufacturing sector.

\footnotetext{
${ }^{13}$ The trends hold similarly in examining the other four dominance indicators (the equivalents to Figure 2 are provided in Appendix Figures A2 through A5).
} 
Figure 2. Regional Industrial Dominance by Census Division.

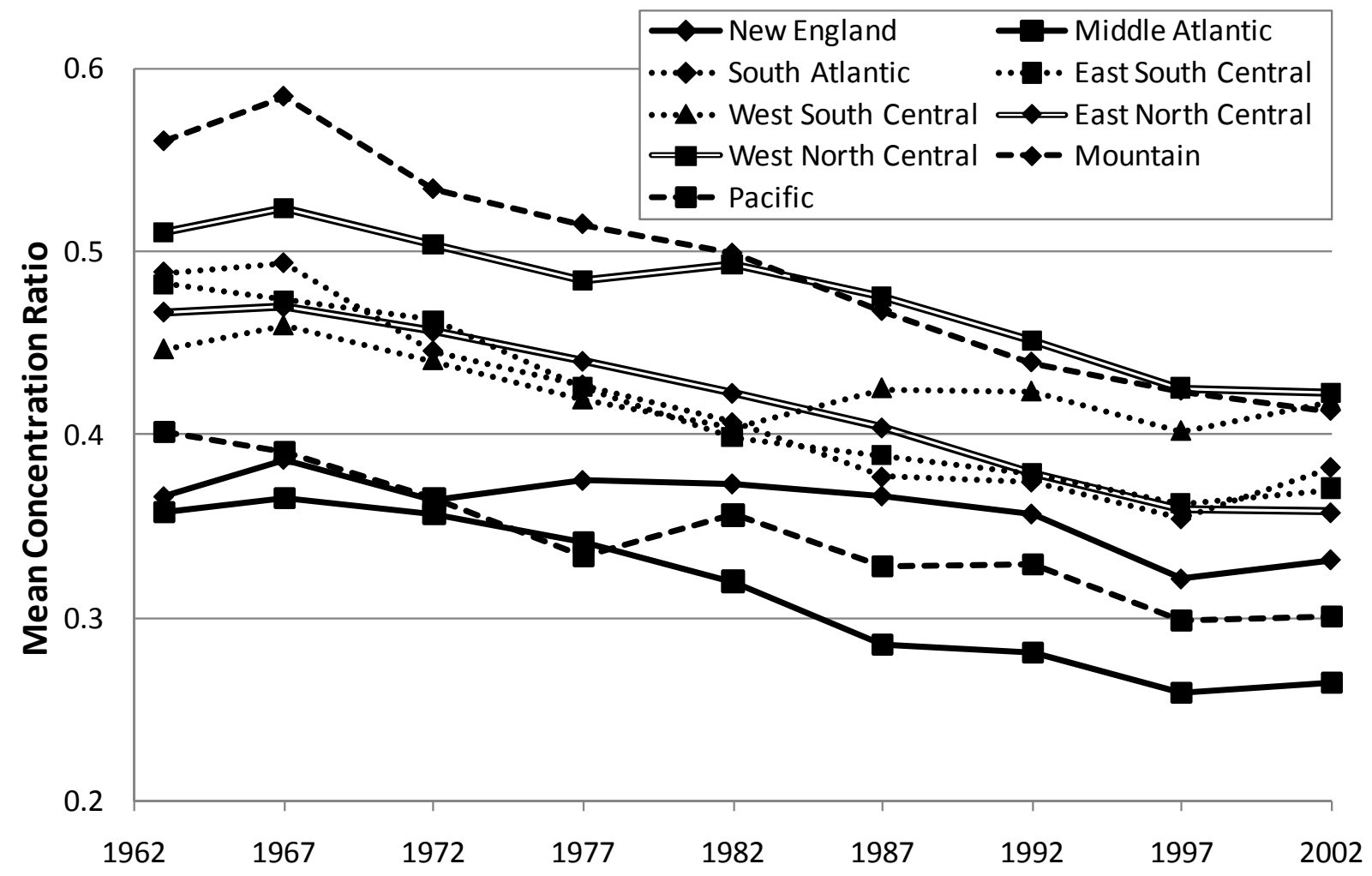

Observations by Census division: New England (12), Middle Atlantic (24), South Atlantic (56), East South Central (24), West South Central (41), East North Central (43), West North Central (27), Mountain (23), Pacific (25).

\section{DOMINANCE AND DECLINE IN THE MANUFACTURING SECTOR}

One of the motivations behind this study is to begin to investigate the relationship between regional industrial dominance and firm performance. As mentioned above, earlier research conducted using the Longitudinal Research Database demonstrates that industryspecific dominance hinders the productivity of small and medium-sized plants in several manufacturing industries. This and the following section examine the relationship between industrial structure and performance more broadly using a regression framework. The analyses are exploratory in nature: the regressions are not presented as full specifications for predicting regional economic performance, but rather as illuminations of the relative strength of the relationships between different aspects of industrial structure and changes occurring in the manufacturing sector at the regional scale. 
This section considers the manufacturing sector as a whole. As in the previous section, each MSA or CMSA provides a separate observation, yielding a sample size of $275 .{ }^{14}$ The dependent variable is the change in employment from 1987 to 1997 . This decade represents the most recent ten-year period available for analysis that avoids the discontinuity from switching industry classification schemes subsequent to 1997. The independent variables are the starting level of manufacturing employment, to account for the differing sizes of the manufacturing sectors across metropolitan regions; regional industrial dominance; and dummy variables for Census regions, with the Northeast region as the default. In addition, the specification includes a measure of regional industrial diversity within the manufacturing sector as another characteristic of industrial structure that empirically has been found to be associated positively with economic performance. As is common in the literature, a Herfindahl-Hirschman index is used to measure diversity. The formula is identical to that in Table 1, but with the subscript $i$ indexing the twodigit SIC industry categories within the manufacturing sector rather than individual firms. As constructed, the Herfindahl-Hirschman index corresponds to the inverse of manufacturing diversity-larger values of the Herfindahl-Hirschman index signify greater concentration within particular industry classifications and a lesser degree of diversity.

Table 4 displays the results of the regression with the independent variable regional industrial dominance measured as the five-firm employment-based concentration ratio. White's general test of first and second moments for heteroskedasticity does not reject homoskedasticity at conventional significance levels. Heteroskedasticity-adjusted probability values are included for completeness, but are little different from the standard estimates. As might be expected, the 1987 count of manufacturing employees is negative and highly significant: in a period of manufacturing decline at the national level, regions with larger manufacturing sectors tended to shed more employment. Metropolitan areas outside of the Northeast experienced greater employment growth, or smaller drops in the number of manufacturing jobs, than regions located within the New England or the Middle Atlantic divisions, with the largest gap between the West and the Northeast Census regions.

\footnotetext{
${ }^{14}$ These 275 MSAs and CMSAs constitute the entire set of metropolitan regions in the continental United States. In other words, the study samples are better characterized as a population than as a representative sample. The implication is that there should be minimal emphasis placed on interpreting inferential statistics with regard to a hypothetical encompassing population, since there are no repeated samples. Therefore, though standard errors and statistical significance are examined to gauge the strength of the estimation results, more attention is placed on interpreting the signs and magnitudes of the estimated parameters (with the exception of the last analytical section in which estimated parameter magnitudes are not provided).
} 
The most important result in Table 4 is that regional industrial dominance is substantially negatively associated with employment change. All else being equal, a region measuring one standard deviation higher than the mean on the concentration ratio measure of manufacturing dominance would be expected to have lost approximately 5,000 more manufacturing jobs over the decade in consideration than a region evidencing the mean level of dominance in 1987 (a five-firm employment concentration ratio of 0.5660 versus 0.3940 ; see Table 2). Without displaying all of the other estimates from the regressions, Table 5 compares the coefficients for the five measures of regional industrial dominance calculated in separate regressions. (The full

Table 4. Regression Results: Manufacturing Sector.

\begin{tabular}{lrrrrr} 
Variable & Coeff. & Std. Err. & t Stat. & p Value & White p Value \\
\hline Intercept & 15,100 & 3,514 & 4.30 & $<.0001 * *$ & $0.0004^{* *}$ \\
1987 Manufacturing Employment & -0.183 & 0.0092 & -19.97 & $<.0001 * *$ & $0.0002 * *$ \\
1987 Dominance (Concentration Ratio) & $-29,760$ & 9,145 & -3.25 & $0.0013 * *$ & $0.0003 * *$ \\
1987 Diversity (Herfindahl-Hirschman) & 9,231 & 19,007 & 0.49 & 0.6276 & 0.3150 \\
South & 1,754 & 2,610 & 0.67 & 0.5020 & 0.3145 \\
Midwest & 4,803 & 4,022 & 1.19 & 0.2334 & 0.1118 \\
West & 6,444 & 3,263 & 1.98 & $0.0493 *$ & 0.0809 \\
Dependent Variable: Employment Change, $1987-1997$. & & & \\
Observations & 275 & & F Stat. & \\
$\mathrm{R}^{2}$ & 0.6168 & F Prob. & \\
Adjusted R $^{2}$ & 0.6082 & White Prob. & \\
\hline
\end{tabular}

* Significant at the $5 \%$ confidence level. ${ }^{* *}$ Significant at the $1 \%$ confidence level.

Table 5. Comparison of Estimated Regional Industrial Dominance Coefficients.

\begin{tabular}{lrrrcrr} 
Variable & Coeff. & Std. Err. & t Stat. & p Value & White $\mathrm{p}$ Value & Effect $\dagger$ \\
\hline Concentration Ratio $\left(\mathrm{D}_{\mathrm{C}}\right)$ & -29760 & 9145 & -3.25 & $0.0013 * *$ & $0.0003 * *$ & -5119 \\
Herfindahl-Hirschman $\left(\mathrm{D}_{\mathrm{H}}\right)$ & -28976 & 23993 & -1.21 & 0.2282 & $0.0208 *$ & -2028 \\
Theil's Entropy $\left(\mathrm{D}_{\mathrm{E}}\right)$ & 9004 & 1499 & 6.01 & $<.0001 * *$ & $0.0001 * *$ & -10319 \\
Rosenbluth $\left(\mathrm{D}_{\mathrm{R}}\right)$ & -184853 & 51092 & -3.62 & $0.0004 * *$ & $0.0018 * *$ & -4991 \\
Gini $\left(\mathrm{D}_{\mathrm{G}}\right)$ & 88353 & 24260 & 3.64 & $0.0003 * *$ & $0.0088 * *$ & 4418 \\
\hline
\end{tabular}

\footnotetext{
${ }^{\dagger}$ Effect refers to the estimated change in manufacturing employment associated with a one standard deviation increase in the regional industrial dominance indicator from its sample mean.
} 
regression results are provided in Tables A1 through A4 in the Appendix.) All four of the absolute measures of dominance demonstrate negative and significant associations with the change in manufacturing employment, and though the estimated impacts of a standard deviation rise in dominance from the mean differ substantially (at least in part due to dissimilar degrees of variation across the sample), they are within a degree of magnitude. Thus the principal resultthat regional industrial dominance is tied to reduced economic performance-holds independently of the particular indicator used to operationalize the dominance concept.

The behavior of the Gini coefficient diverges from the pattern established with the other indicators of regional industrial dominance. Greater inequality in firm size is associated with larger manufacturing employment gains, or more accurately smaller employment declines, between 1987 and 1997. Again, this finding suggests a more complex dynamic than is observed considering the absolute dominance measures alone. Metropolitan regions with less concentration of manufacturing employment in the very largest companies display superior economic performance in terms of job growth or retention, but so do regions with greater inequality in firm size.

This seeming contradiction may be reconciled by considering the role of scale. In measuring dominance, concentration ratios, Theil's entropy measure, and the HerfindahlHirschman and Rosenbluth indices all tend to be negatively associated with the size of the industry or sector. At least in numerical terms, it is more difficult to "dominate" a larger region (Drucker 2007). The Gini coefficient, by construction, is unrelated to scale. Over the decade examined, holding the control variables constant, manufacturing job losses were the least in those regions with an unequal firm size distribution (i.e., a wide range of company sizes) but with manufacturing sectors not too extensively concentrated in a few large firms. These conditions are more likely to be achieved in larger regions. Thus, this line of reasoning may seem to return to the proposition that overall industry size boosts economic performance. Yet, as was discussed earlier, industry scale does not provide a conceptual explanation for impacts on economic performance, but acts as a proxy for various types of interfirm relationships. This exploratory analysis cannot answer the causal question of whether larger regions tend to have industrial structures more favorable to employment retention, or instead lower dominance levels and wider firm size distributions are found in populous metropolitan regions that also tend to enjoy superior manufacturing performance for more fundamental or for unrelated reasons. The 
author's previous research on the topic suggests that the former is the case - that industrial structure is a causal factor-but the issue remains open for further empirical research (Drucker and Feser 2007).

Table 4 also reports that industrial diversity is negatively and not significantly associated with gains in employment. (Larger values of the Herfindahl-Hirschman index represent less industrial diversity.) This may be at least in part because the Herfindahl-Hirschman measure has a relatively small mean in absolute terms, and exhibits quite limited variation across metropolitan regions. ${ }^{15}$ In addition, regional industrial diversity and dominance are negatively correlated: dominated regions tend not to be diverse, and diverse areas are usually less dominated. This relates again to the issue of scale, as larger regions typically possess greater industrial diversity. Nevertheless, dominance certainly is more powerfully associated with employment change than is industrial diversity, as evidenced in Table 4 (and the equivalent tables in the Appendix for the other measures of dominance) as well as through robustness tests. Regressions that alternately omit dominance and industrial diversity confirm that each variable attains the expected sign and increases in significance in the other's absence. ${ }^{16}$ Yet the regional industrial dominance variable remains the greater in terms of significance and the magnitude of the estimated impact on employment change.

It is worth describing several alternative regressions that were estimated to judge the sensitivity of the findings to the particular specification and variable definitions. (The results are omitted to reduce disclosure screening requirements.) Substituting the change in shipments or in value-added for employment as the dependent variable generated similar but less consistently significant coefficients; it makes sense that with dominance and diversity measured on an employment basis, a dependent variable also defined in terms of employment yields the strongest results. Regional dominance is an enduring phenomenon: instituting a ten-year lag in the regional industrial dominance variable produced almost identical regression outcomes. Incorporating interaction terms between dominance and the Census region variables demonstrated that regional industrial dominance has its greatest negative association with manufacturing employment growth in the West region. Three dummy variables categorizing the

\footnotetext{
${ }^{15}$ Variable descriptive statistics are not presented due to disclosure considerations.

${ }^{16}$ Similarly, among the regressions employing the five different measures of regional industrial dominance, the industrial diversity variable achieves its greatest estimated significance, in the expected negative direction, when dominance is measured with the Gini coefficient (see Table A4).
} 
urban hierarchy according to metropolitan population level were used to help verify that larger regions outperformed smaller areas in manufacturing employment growth controlling for base year employment levels. The two larger but not the two smaller size categories yielded positive and significant coefficients, and interactions between the metropolitan size variables and regional industrial dominance were not significant. Finally, other alterations that yielded findings substantively similar to those presented above included examining different time periods (the five-year periods from 1987 to 1992 and 1992 to 1997, as well as alternative decades), using the competitive shift component from a classical shift-share decomposition as the dependent variable, and specifying dummies for Census divisions rather than regions.

\section{DOMINANCE, DIVERSITY, AND INDUSTRY PERFORMANCE}

This section extends the examination of the relationships between industrial structure and performance by disaggregating the manufacturing sector into component industries. Separate regressions are performed for the two-digit SIC industries within the manufacturing sector. (Table 6 lists these industries.) The units of analysis remain MSAs and CMSAs, but for each industry the set of metropolitan regions is restricted to those with at least twelve firms in the industry in 1987 in order to ensure the meaningfulness of the intra-industry dominance concept. A few of the two-digit industries have twelve or more firms in only a small number of metropolitan areas, so the regression estimations may not be very precise; the extreme case is SIC 21 (tobacco products), for which only one region has at least twelve firms. For most of the industries, however, the sample size is sufficient to support robust regression analyses.

The dependent variable in each regression is the change in industry employment from 1987 to 1997 . Most of the independent variables are the same as or equivalent to those used in the manufacturing-wide regressions described in the previous section: the 1987 level of industry employment controls for varying industry size across regions; manufacturing sector diversity is indicated by a Herfindahl-Hirschman index calculated across 2-digit SIC industry categories; dummy variables denote three Census regions leaving the Northeast as the base. The estimations incorporate regional industrial dominance at two levels of aggregation: industry-specific, and across the entire manufacturing sector. The same type of measure is used to calculate these two dominance variables within each regression. Industrial specialization or concentration is added 
Table 6. Two-digit SIC Industries.

\begin{tabular}{clrr} 
SIC & Industry & $\begin{array}{r}\text { 1997 Total U.S. } \\
\text { Establishments }\end{array}$ & $\begin{array}{r}1997 \text { Total U.S. } \\
\text { Employment }\end{array}$ \\
\hline 20 & Food and kindred products & 21,223 & $1,539,682$ \\
21 & Tobacco products & 142 & 34,166 \\
22 & Textile mill products & 6,190 & 553,198 \\
23 & Apparel and other textile products & 23,939 & 835,219 \\
24 & Lumber and wood products & 37,207 & 745,254 \\
25 & Furniture and fixtures & 12,222 & 514,504 \\
26 & Paper and allied products & 6,542 & 621,072 \\
27 & Printing and publishing & 62,577 & $1,501,714$ \\
28 & Chemicals and allied products & 12,386 & 832,546 \\
29 & Petroleum and coal products & 2,144 & 107,829 \\
30 & Rubber and miscellaneous plastics products & 16,814 & $1,015,177$ \\
31 & Leather and leather products & 1,861 & 83,387 \\
32 & Stone, clay, and glass products & 16,570 & 500,828 \\
33 & Primary metal industries & 6,628 & 686,161 \\
34 & Fabricated metal products & 38,691 & $1,537,591$ \\
35 & Industrial machinery and equipment & 56,696 & $1,954,761$ \\
36 & Electronic and other electical equipment & 17,398 & $1,528,348$ \\
37 & Transportation equipment & 12,677 & $1,573,789$ \\
38 & Instruments and related products & 11,941 & 813,612 \\
39 & Miscellaneous manufacturing industries & 18,471 & 399,391 \\
\hline
\end{tabular}

Source: County Business Patterns (United States Census Bureau, n.d.).

as an aspect of regional economic composition relevant for industry-specific analysis and is measured by a location quotient calculated relative to the national manufacturing sector. Because of the smaller number of observations involved in these regressions, significance is reported at the 10 percent as well as the 5 percent and 1 percent confidence levels.

Table 7 summarizes the results obtained using the five-firm concentration ratio measure of dominance. The signs and significance ranges but not the estimated parameters are presented for individual coefficients. This reduces disclosure concerns and also facilitates visual comparisons across the series of regressions. The coefficients of determination $\left(\mathrm{R}^{2}\right)$ demonstrate that the degree to which the set of independent variables explain the regional variation in employment change over the decade varies widely by industry, as should be expected given the exploratory nature of the analysis. As in the manufacturing-wide analysis, the estimated 
Table 7. Regression Results: Industries (Concentration Ratio Dominance).

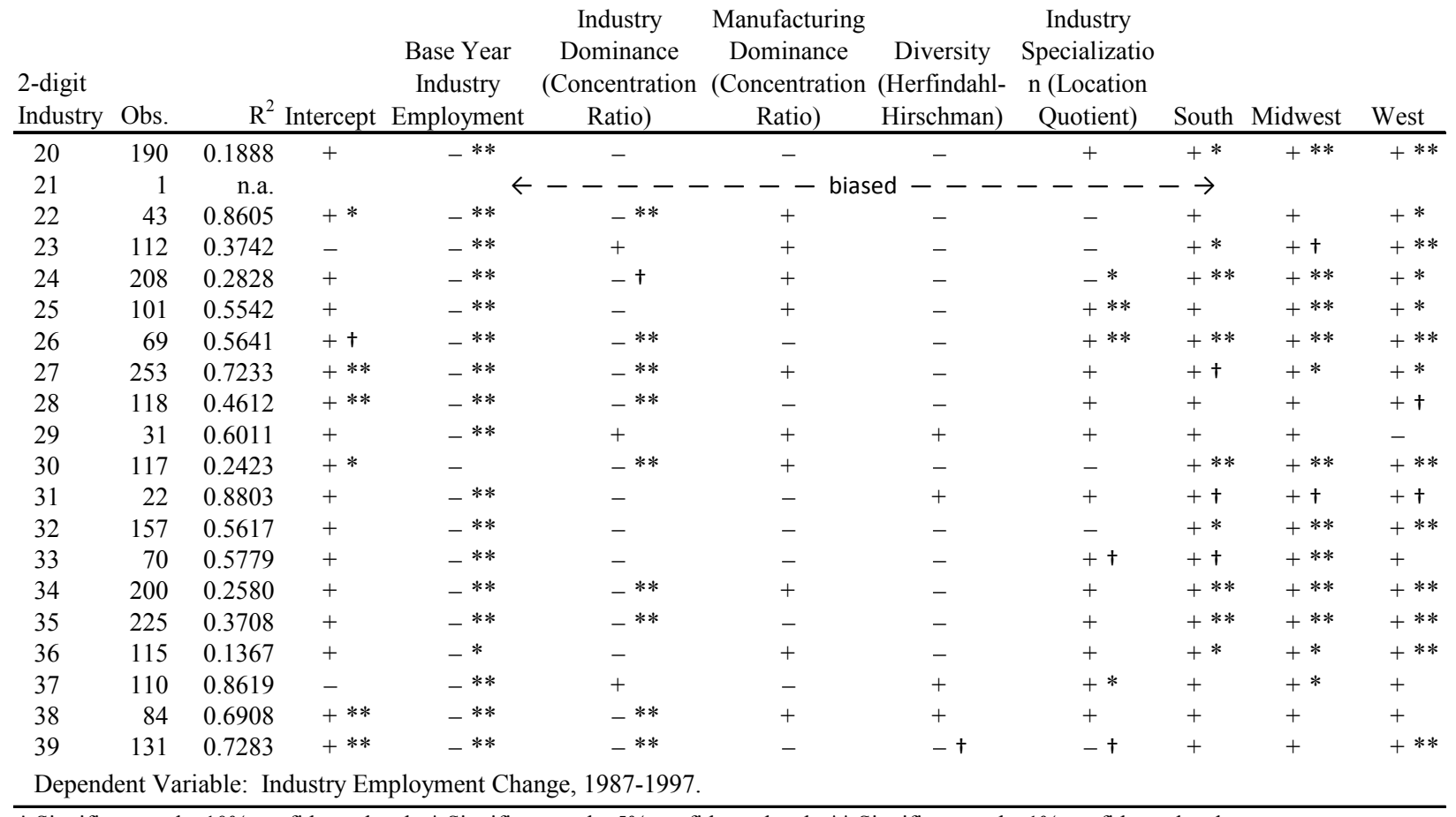

† Significant at the $10 \%$ confidence level. * Significant at the $5 \%$ confidence level. ${ }^{* *}$ Significant at the $1 \%$ confidence level.

parameters of the 1987 industry employment levels are uniformly negative. Nearly all are highly significant as well: regions with larger industries lost more employment over the decade. Also as before, the Northeast Census region underperformed the South, Midwest, and West in retaining manufacturing jobs in nearly every industry.

Turning to the industrial structure variables, the degree of regional dominance in the particular industry is the most important. Industry-specific dominance is negative and significant in about half of the industries, ranging across the manufacturing spectrum from textile mills (SIC 22) and paper production (SIC 26) to chemicals and pharmaceuticals (SIC 28), instruments (SIC 38), and industrial equipment (SIC 35). Several of the industries in which the industry-specific dominance variable does not attain conventional significance levels are those with relatively small numbers of suitable metropolitan regions as observations, such as petroleum and coal (SIC 29), leather (SIC 31), and primary metals (SIC 33). There does not seem to be any obvious pattern across the industries, such as regarding the technology or knowledge basis or relative intensity of capital versus labor in production. 
The other industrial structure variables are far less prominent in the estimated models. Controlling for industry-specific dominance, neither overall manufacturing dominance nor manufacturing diversity is significantly associated with the change in industry employment. As discussed in the preceding section, overall manufacturing dominance is negatively correlated with manufacturing diversity. ${ }^{17}$ Yet regressions that exclude one or the other variable do not generate significant coefficients for the remaining variable. Industry specialization is strongly positively linked to job growth or retention in the furniture and fixtures (SIC 25), paper (SIC 26), and transportation equipment (SIC 37) industries. The impact of industry specialization is marginally significant in just a few additional industries, with the direction of the relationship in some estimated to be negative rather than positive. On the whole, regional industrial dominance is associated with lesser employment growth independently of local industrial concentration, diversity, and overall manufacturing dominance.

The results are much the same when the concentration ratio measures of industry-specific and manufacturing-wide regional dominance are replaced by the Herfindahl-Hirschman index, Theil's entropy measure, or the Rosenbluth index. Table 8 lists the outcomes just for the industry-specific dominance variables. (The other outcomes do not change substantively. The individual regression summaries are available upon request from the author.) The signs and significance levels of the variables are largely consistent across the different measures of dominance (allowing for the reversal of sign with Theil's entropy measure), though the results are noticeably weaker for the Rosenbluth index in some industries. The set of smaller firms considered together may be less influential in certain industries than in others because of the particular shape of the firm size distribution or due to other industry-specific characteristics. The Gini coefficient yields few significant impacts, suggesting that size inequality is involved in the performance of the entire manufacturing sector but is not influential at the scale of individual regional industries.

\footnotetext{
${ }^{17}$ Manufacturing-wide and industry-specific regional dominance are correlated to a much lesser degree, in the positive direction.
} 
Table 8. Comparison of Industry-Specific Dominance Coefficients.

\begin{tabular}{|c|c|c|c|c|c|c|}
\hline $\begin{array}{l}\text { 2-digit } \\
\text { Industry }\end{array}$ & Obs. & $\begin{array}{c}\text { Concentration } \\
\text { Ratio } \\
\text { Dominance }\end{array}$ & $\begin{array}{l}\text { Herfindahl- } \\
\text { Hirschman } \\
\text { Dominance }\end{array}$ & $\begin{array}{c}\text { Theil's } \\
\text { Entropy } \\
\text { Dominance }\end{array}$ & $\begin{array}{l}\text { Rosenbluth } \\
\text { Dominance }\end{array}$ & $\begin{array}{c}\text { Gini } \\
\text { Dominance }\end{array}$ \\
\hline 20 & 190 & - & - & + & - & + \\
\hline 21 & 1 & $\leftarrow--$ & ---- & - biased - & --- & $--\rightarrow$ \\
\hline 22 & 43 & $-* *$ & $-*$ & $+* *$ & $-*$ & - \\
\hline 23 & 112 & + & + & + & + & - \\
\hline 24 & 208 & $-\dagger$ & - & + & $-\dagger$ & + \\
\hline 25 & 101 & - & - & + & - & + \\
\hline 26 & 69 & $-* *$ & $-\dagger$ & $+*$ & - & + \\
\hline 27 & 253 & $-* *$ & $-* *$ & $+* *$ & $-* *$ & + \\
\hline 28 & 118 & $-* *$ & $-* *$ & $+*$ & $-* *$ & + \\
\hline 29 & 31 & + & - & + & + & - \\
\hline 30 & 117 & $-* *$ & $-*$ & $+* *$ & - & + \\
\hline 31 & 22 & - & + & - & - & + \\
\hline 32 & 157 & - & - & + & - & $+* *$ \\
\hline 33 & 70 & - & $-* *$ & $+*$ & $-*$ & $-*$ \\
\hline 34 & 200 & $-* *$ & $-*$ & $+* *$ & - & - \\
\hline 35 & 225 & $-* *$ & - & $+* *$ & - & + \\
\hline 36 & 115 & - & $-\dagger$ & + & - & - \\
\hline 37 & 110 & + & + & - & - & + \\
\hline 38 & 84 & $-* *$ & $-* *$ & $+* *$ & $-*$ & + \\
\hline 39 & 131 & $-* *$ & $-{ }^{\dagger}$ & $+*$ & - & ++ \\
\hline \multicolumn{7}{|c|}{ Dependent Variable: Industry Employment Change, 1987-1997. } \\
\hline
\end{tabular}

+ Significant at the $10 \%$ confidence level. * Significant at the $5 \%$ confidence level.

** Significant at the $1 \%$ confidence level.

\section{SUMMARY AND IMPLICATIONS}

Benjamin Chinitz's article provoked interest in the importance of industrial structure at the regional scale, yet the topic of regional dominance has not been investigated systematically in the decades that have followed. Recent research by the author finds that regional industrial dominance hampers the productivity of manufacturing plants in selected United States industries, providing motivation for a broader exploratory analysis. This study uses confidential establishment-level data to describe historical and geographic patterns in industrial concentration across U.S. metropolitan regions and to examine the associations among economic performance, industrial dominance, and other facets of regional industrial structure. 
Regional dominance in the manufacturing sector has been steadily diminishing since at least the early 1970s. Total employment and average plant size in the manufacturing sector nationwide have dropped during the same time period but the Gini indicator of firm size inequality has remained stable, suggesting that declining regional dominance may result from proportionally greater employment drops in large firms and production outsourcing to smaller manufacturers and service firms. The reduction in regional dominance has occurred across all geographic segments of the continental United States, but to a greater degree in areas with higher levels of dominance and perhaps less mature manufacturing sectors at the beginning of the study period. The Middle Atlantic and Pacific coastal areas have retained their positions as containing (on average) the least dominated metropolitan regions.

Regional dominance is linked strongly to slower employment growth or greater employment declines both across the manufacturing sector and within most component manufacturing industries. Employment change at the regional scale is much more powerfully associated with dominance than with other aspects of industrial structure such as industrial diversity or specialization. The degree to which dominance and employment change are associated for particular manufacturing industries does not seem to depend on industry characteristics such as technology or capital intensity in production. Controlling for base levels of employment, larger metropolitan regions tend to exhibit superior manufacturing job performance as well as lower levels of dominance, but it cannot be ascertained in this analysis whether the two phenomena are causally related.

The study highlights the significance of industrial structures at the regional scale, and at the same time raises additional questions for economic development researchers and practitioners. The primary findings confirm the importance of industrial dominance as an aspect of regional industrial structure that is influentially related to both industry-specific and manufacturing-sector economic performance. Economic analysts and economic development practitioners that currently examine overall regional concentration and perhaps industry concentrations at the national level should pay attention to concentration and dominance at the level of regional industries. Although regional dominance in manufacturing has declined in absolute terms along with the scale of the sector within the national economy, dominance remains strongly associated with changes in employment. The relative degree of dominance may differentiate among industries and metropolitan regions in terms of economic performance. The 
coastal regions that lead the nation in technological innovation, business creation, and economic dynamism also evidence the lowest average regional industrial dominance. Useful extensions for future research would include examining trends in regional dominance in sectors and industries outside of manufacturing, such as in the rapidly expanding service and retail segments of the economy, and investigating the relationships between manufacturing dominance and production fragmentation and outsourcing.

Despite the ambiguity of the causal relationship between dominance and employment change, the research implies that regionally dominated industries are likely to face challenges in terms of economic resiliency and adaptability. Regional dominance may possibly cause, but at least serves to reveal, structural impediments to employment creation that may similarly impede productivity, innovation, entrepreneurship, and business expansion, reducing the capacity of industries and economies to react flexibly to changing economic conditions. Restructuring in the face of global economic changes or economic upheavals may occur more slowly in dominated regions or industries or may be unsuccessful altogether. The goal of developing policies to address the issues that arise from disadvantageous regional industrial structures should provide further impetus for research on the topic.

The findings also underscore the challenge of devising appropriate economic development policies. Regional industrial dominance is a phenomenon that by its nature is likely to endure over time and is difficult to alter directly with the policy tools available at the local and regional levels. Direct attempts to modify regional industrial structures other than through massive (and expensive) recruitment plans are likely to be politically untenable as well as economically infeasible, and without additional knowledge it is difficult to devise more subtle programs to help industries and regional economies counter the possible negative implications of a non-competitive regional corporate structure. It is clear that more research on the specific linkages between dominance and economic performance is needed. Nevertheless, simply understanding that regional industrial dominance is an issue that affects economic performance may engender creativity, both in designing policies to counter the influence of dominance and in shaping policies to work within local economic conditions. 


\section{APPENDICES}

Figure A1. Census Regions and Divisions.

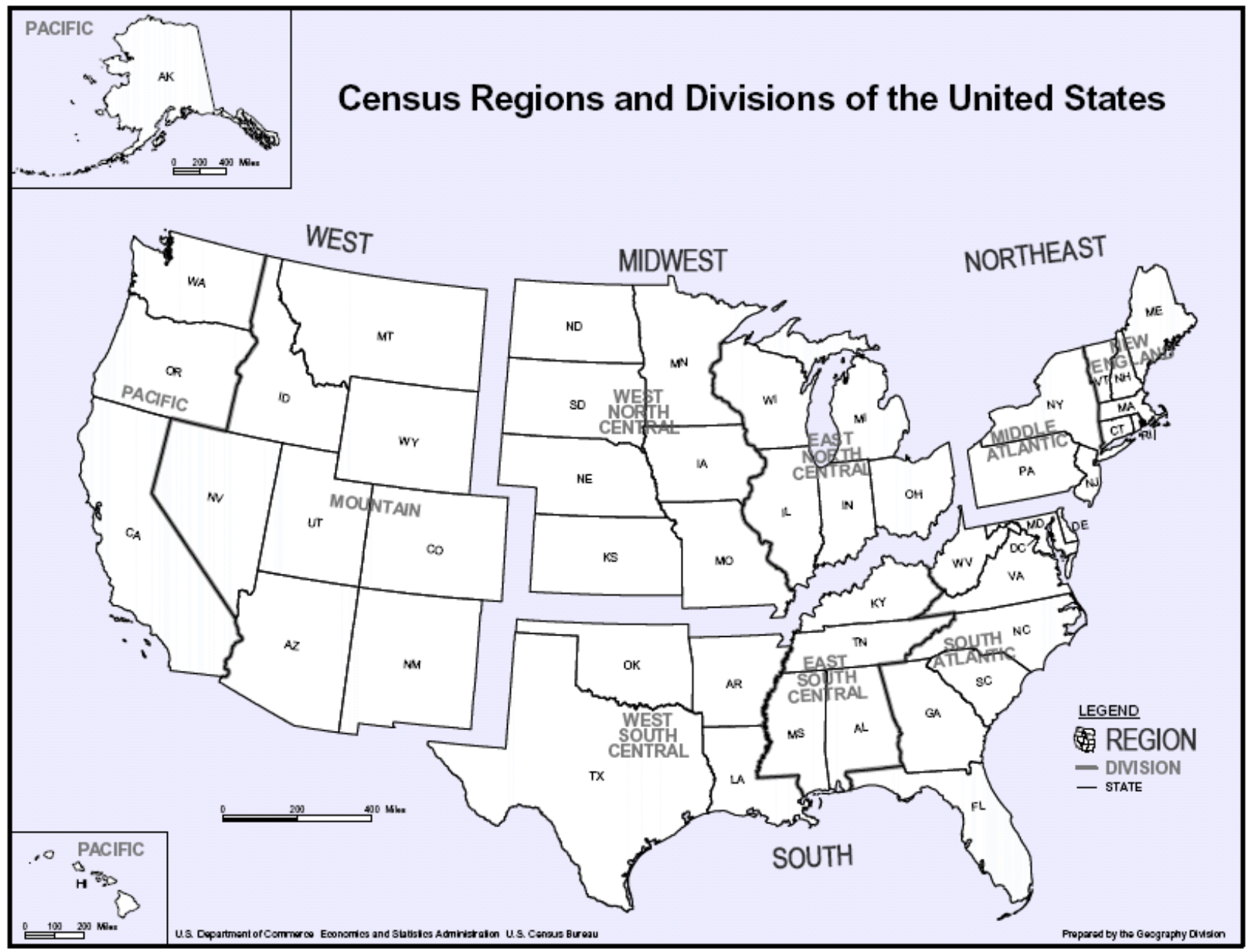

Source: United States Census Bureau (n.d.-b). 
Figure A2. Regional Industrial Dominance (Herfindahl-Hirschman Index) by Census Division.

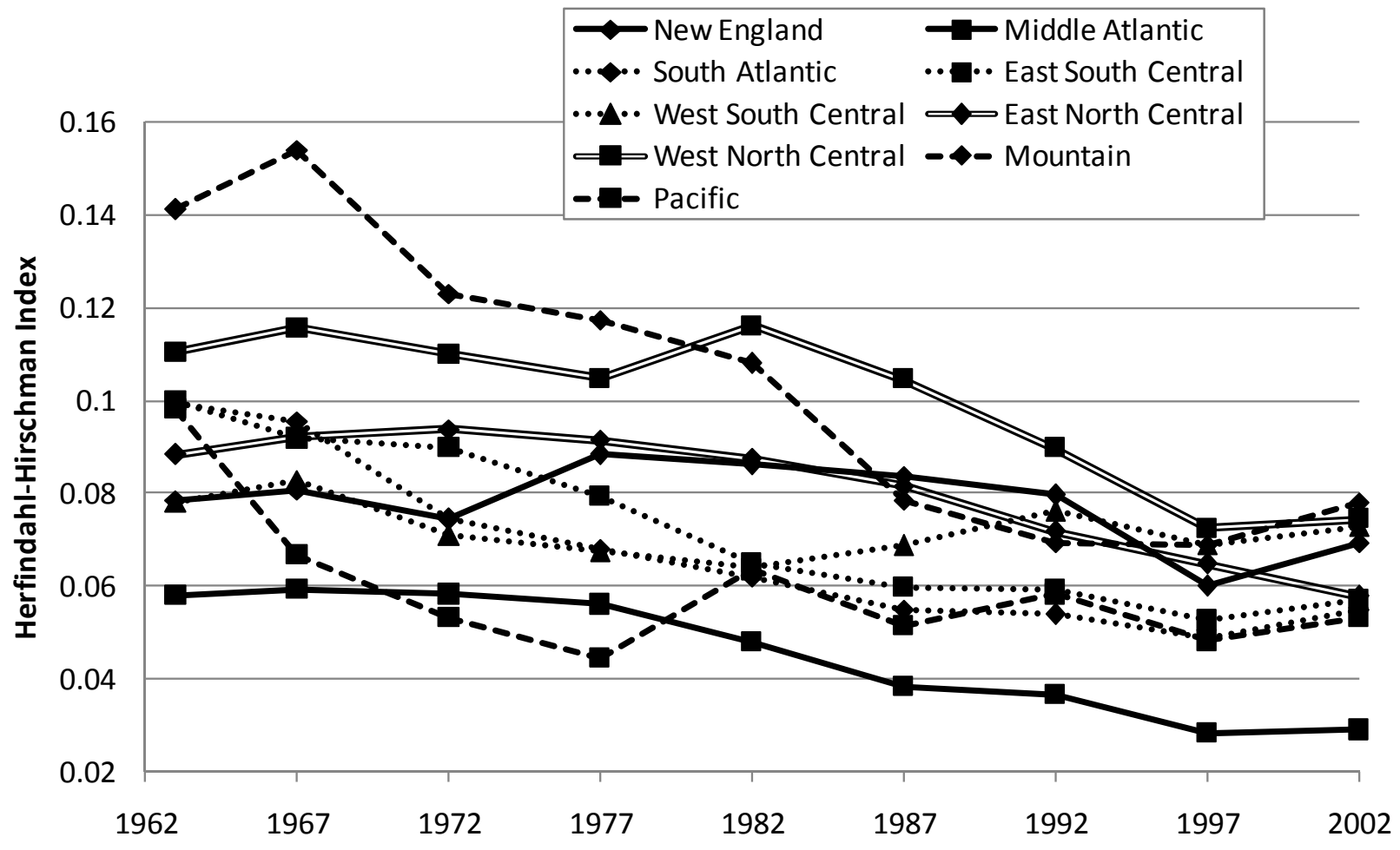

Figure A3. Regional Industrial Dominance (Theil's Entropy) by Census Division.

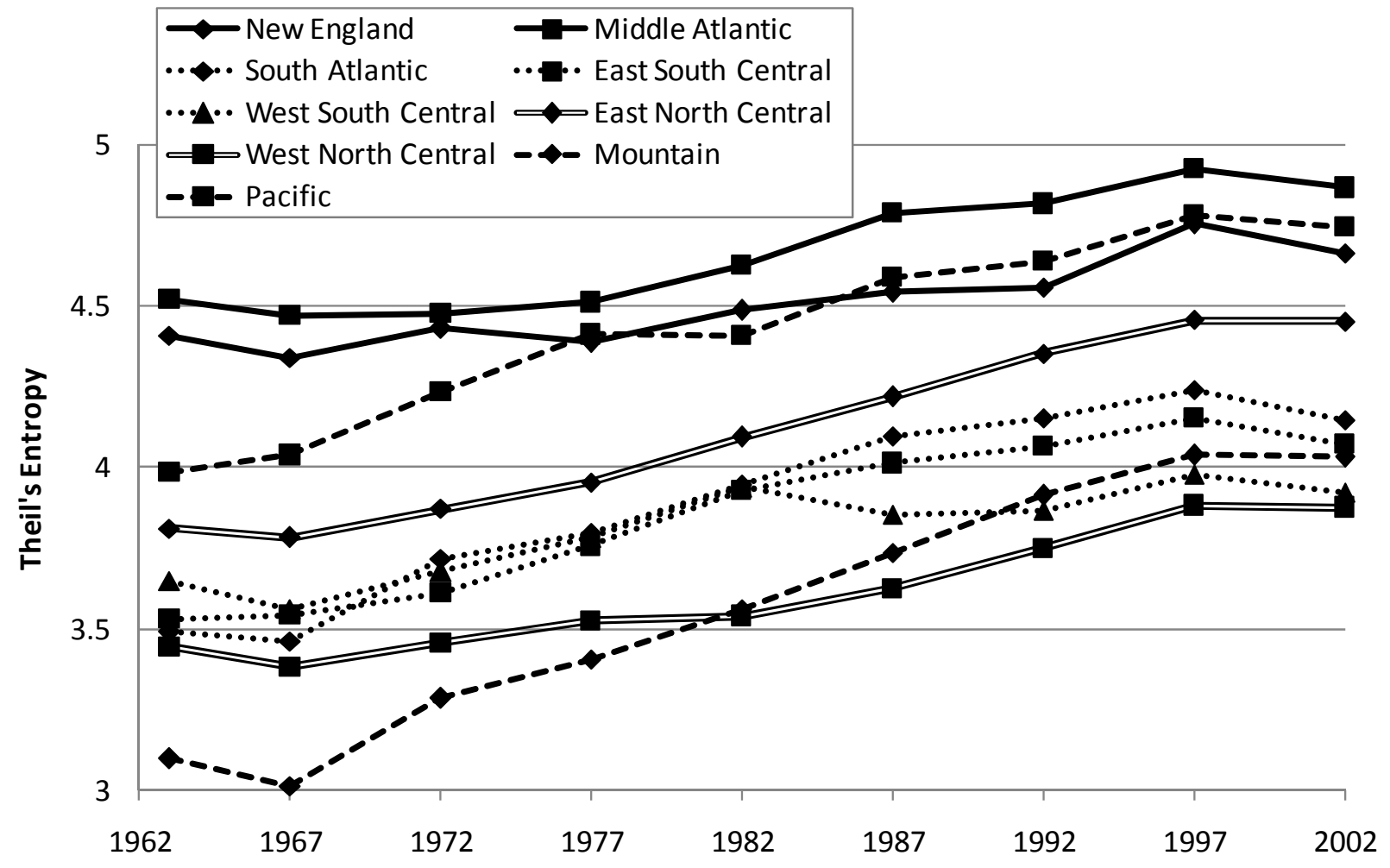


Figure A4. Regional Industrial Dominance (Rosenbluth Index) by Census Division.

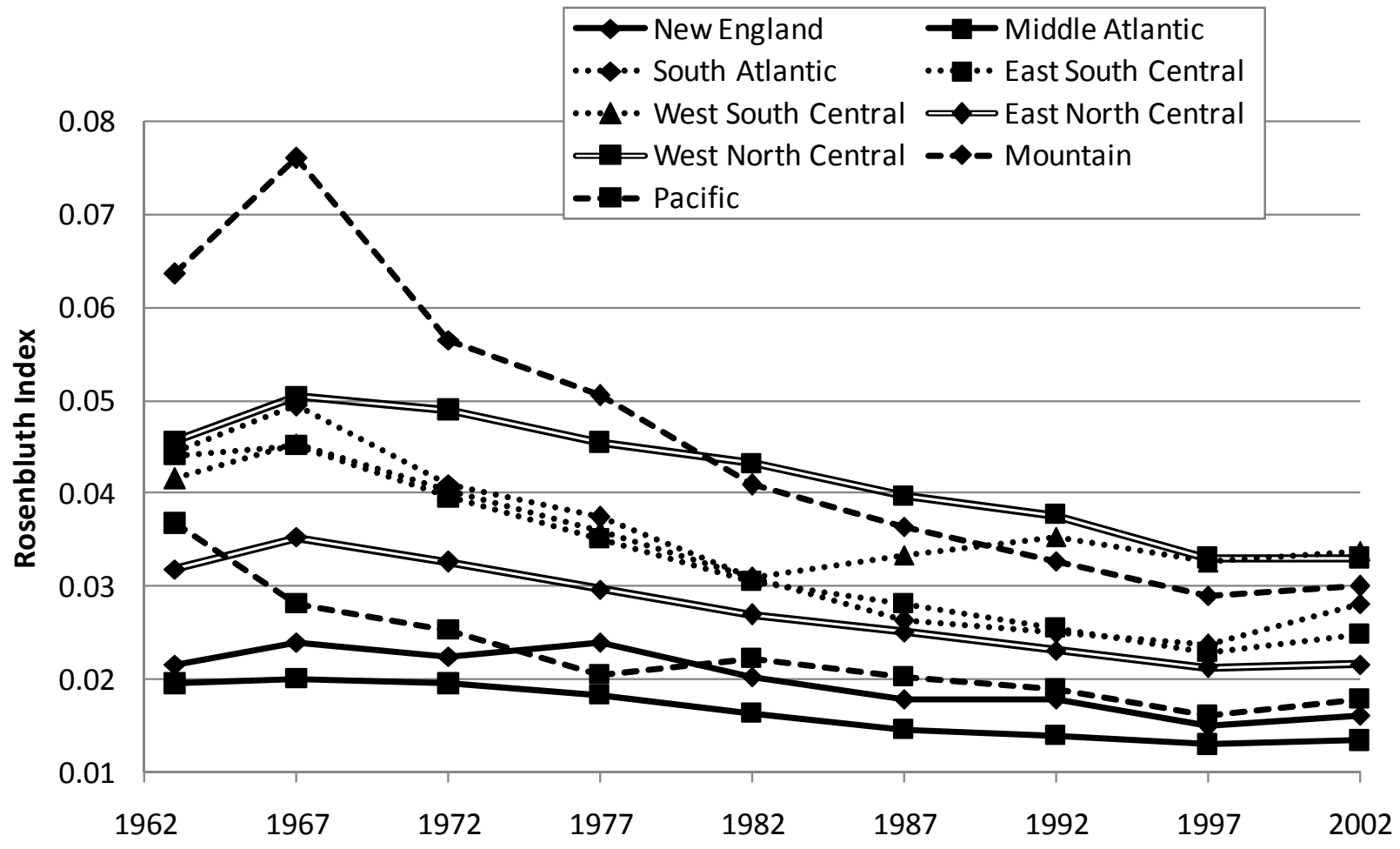

Figure A5. Regional Industrial Dominance (Gini Coefficient) by Census Division.

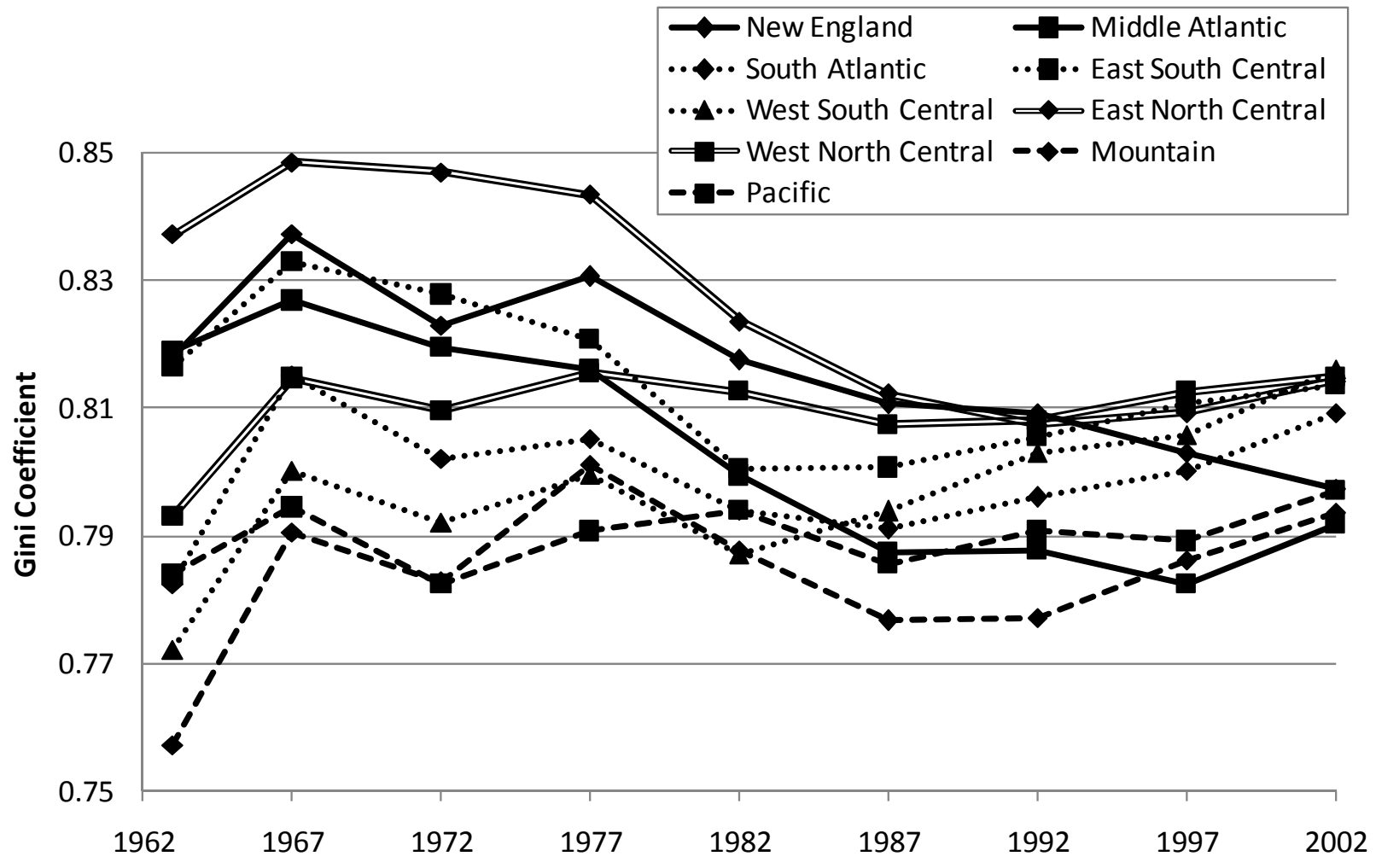


Table A1. Regional Industrial Dominance in Manufacturing by Census Division.

\begin{tabular}{cccccccccccc} 
Year & & 1963 & 1967 & 1972 & 1977 & 1982 & 1987 & 1992 & 1997 & 2002 \\
\hline Census Division & & & & & & & & & & & \\
New England & mean & 0.3664 & 0.3866 & 0.3643 & 0.3752 & 0.3733 & 0.3668 & 0.3570 & 0.3218 & 0.3322 \\
(12 observations) & std dev. & 0.2032 & 0.2172 & 0.2131 & 0.2323 & 0.2279 & 0.2093 & 0.2021 & 0.1946 & 0.1905 \\
Middle Atlantic & mean & 0.3584 & 0.3659 & 0.3574 & 0.3419 & 0.3202 & 0.2858 & 0.2812 & 0.2592 & 0.2646 \\
(24 observations) & std dev. & 0.1805 & 0.1747 & 0.1689 & 0.1554 & 0.1404 & 0.1334 & 0.1269 & 0.1228 & 0.1068 \\
South Atlantic & mean & 0.4891 & 0.4941 & 0.4461 & 0.4276 & 0.4070 & 0.3774 & 0.3746 & 0.3546 & 0.3826 \\
(56 observations) & std dev. & 0.1735 & 0.1784 & 0.1730 & 0.1648 & 0.1532 & 0.1448 & 0.1425 & 0.1481 & 0.1703 \\
East South Central & mean & 0.4824 & 0.4735 & 0.4631 & 0.4263 & 0.3986 & 0.3886 & 0.3792 & 0.3627 & 0.3708 \\
(24 observations) & std dev. & 0.1955 & 0.1815 & 0.1785 & 0.1804 & 0.1690 & 0.1689 & 0.1652 & 0.1554 & 0.1412 \\
West South Central & mean & 0.4466 & 0.4596 & 0.4406 & 0.4192 & 0.4038 & 0.4254 & 0.4236 & 0.4021 & 0.4186 \\
(41 observations) & std dev. & 0.1713 & 0.1628 & 0.1536 & 0.1480 & 0.1555 & 0.1569 & 0.1726 & 0.1744 & 0.1782 \\
East North Central & mean & 0.4671 & 0.4699 & 0.4564 & 0.4403 & 0.4229 & 0.4041 & 0.3789 & 0.3590 & 0.3580 \\
(43 observations) & std dev. & 0.1759 & 0.1835 & 0.1964 & 0.1974 & 0.1955 & 0.1934 & 0.1934 & 0.1904 & 0.1855 \\
West North Central & mean & 0.5103 & 0.5237 & 0.5044 & 0.4840 & 0.4932 & 0.4756 & 0.4511 & 0.4254 & 0.4228 \\
(27 observations) & std dev. & 0.1654 & 0.1738 & 0.1752 & 0.1807 & 0.1943 & 0.1757 & 0.1846 & 0.1717 & 0.1827 \\
Mountain & mean & 0.5606 & 0.5850 & 0.5344 & 0.5152 & 0.4992 & 0.4677 & 0.4396 & 0.4241 & 0.4130 \\
(23 observations) & std dev. & 0.1559 & 0.1893 & 0.1742 & 0.1835 & 0.1634 & 0.1654 & 0.1631 & 0.1694 & 0.1847 \\
Pacific & mean & 0.4019 & 0.3905 & 0.3653 & 0.3340 & 0.3565 & 0.3286 & 0.3293 & 0.2987 & 0.3009 \\
(25 observations) & std dev. & 0.1848 & 0.1598 & 0.1530 & 0.1291 & 0.1696 & 0.1637 & 0.1771 & 0.1684 & 0.1751 \\
\hline
\end{tabular}

Table A2. Regression Results: Manufacturing Sector (Herfindahl-Hirschman Dominance).

\begin{tabular}{lrrrrc} 
Variable & Coeff. & Std. Err. & t Stat. & p Value & White p \\
\hline Intercept & 9,128 & 3,282 & 2.78 & $0.0058^{* *}$ & $0.0038^{* *}$ \\
1987 Manufacturing Employment & -0.175 & 0.0089 & -19.63 & $<.0001 * *$ & $0.0003 * *$ \\
1987 Dominance (Herfindahl-Hirschman) & $-28,976$ & 23,993 & -1.21 & 0.2282 & $0.0208^{*}$ \\
1987 Diversity (Herfindahl-Hirschman) & $-13,353$ & 21,277 & -0.63 & 0.5308 & 0.1958 \\
South & 834 & 2,648 & 0.31 & 0.7531 & 0.6382 \\
Midwest & 4,125 & 4,085 & 1.01 & 0.3135 & 0.1842 \\
West & 6,214 & 3,366 & 1.85 & 0.0660 & 0.1044 \\
Dependent Variable: Employment Change, $1987-1997$. & & & \\
Observations & 275 & & F Stat. & \\
$\mathrm{R}^{2}$ & 0.6038 & F Prob. & \\
Adjusted R $^{2}$ & 0.5949 & White Prob. & \\
\hline
\end{tabular}

* Significant at the $5 \%$ confidence level. ${ }^{* *}$ Significant at the $1 \%$ confidence level. 
Table A3. Regression Results: Manufacturing Sector (Theil's Entropy Dominance).

\begin{tabular}{lrrrcc} 
Variable & Coeff. & Std. Err. & t Stat. & p Value & White p \\
\hline Intercept & $-35,970$ & 8,224 & -4.37 & $<.0001 * *$ & $0.0004^{* *}$ \\
1987 Manufacturing Employment & -0.218 & 0.0111 & -19.64 & $<.0001 * *$ & $0.0001 * *$ \\
1987 Dominance (Theil's Entropy) & 9,004 & 1,499 & 6.01 & $<.0001 * *$ & $0.0001 * *$ \\
1987 Diversity (Herfindahl-Hirschman) & 29,831 & 16,983 & 1.76 & 0.0801 & $0.0148 *$ \\
South & 2,996 & 2,510 & 1.19 & 0.2336 & 0.0920 \\
Midwest & 5,847 & 3,855 & 1.52 & 0.1305 & $0.0387 *$ \\
West & 6,342 & 3,121 & 2.03 & $0.0431 *$ & 0.0705
\end{tabular}

Dependent Variable: Employment Change, 1987-1997.

$\begin{array}{lrlr}\text { Observations } & 275 & \text { F Stat. } & 82.55 \\ \mathrm{R}^{2} & 0.6489 & \text { F Prob. } & <.0001 \\ \text { Adjusted } \mathrm{R}^{2} & 0.6410 & \text { White Prob. } & 0.0667\end{array}$

* Significant at the $5 \%$ confidence level. ${ }^{* *}$ Significant at the $1 \%$ confidence level.

Table A4. Regression Results: Manufacturing Sector (Rosenbluth Dominance).

\begin{tabular}{lrrrrr} 
Variable & Coeff. & Std. Err. & t Stat. & p Value & White p \\
\hline Intercept & 8,943 & 3,147 & 2.84 & $0.0048 * *$ & $0.0029 * *$ \\
1987 Manufacturing Employment & -0.181 & 0.0089 & -20.33 & $<.0001 * *$ & $0.0002 * *$ \\
1987 Dominance (Rosenbluth) & $-184,853$ & 51,092 & -3.62 & $0.0004 * *$ & $0.0018^{* *}$ \\
1987 Diversity (Herfindahl-Hirschman) & 2,924 & 17,066 & 0.17 & 0.8641 & 0.7510 \\
South & 2,372 & 2,615 & 0.91 & 0.3651 & 0.1985 \\
Midwest & 5,385 & 4,013 & 1.34 & 0.1808 & 0.0890 \\
West & 7,055 & 3,245 & 2.17 & $0.0306 *$ & 0.0576 \\
Dependent Variable: Employment Change, $1987-1997$. & & & \\
Observations & 275 & & F Stat. & & 72.93 \\
$\mathrm{R}^{2}$ & 0.6202 & F Prob. & & \\
Adjusted $\mathrm{R}^{2}$ & 0.6117 & White Prob. & 0.3475 \\
\hline
\end{tabular}

* Significant at the $5 \%$ confidence level. ** Significant at the $1 \%$ confidence level. 
Table A5. Regression Results: Manufacturing Sector (Gini Dominance).

\begin{tabular}{lrrrrc} 
Variable & Coeff. & Std. Err. & t Stat. & p Value & White p \\
\hline Intercept & $-56,587$ & 18,552 & -3.05 & $0.0025^{* *}$ & $0.0161^{*}$ \\
1987 Manufacturing Employment & -0.181 & 0.0089 & -20.35 & $<.0001 * *$ & $0.0002^{* *}$ \\
1987 Dominance (Gini Coefficient) & 88,353 & 24,260 & 3.64 & $0.0003 * *$ & $0.0088^{* *}$ \\
1987 Diversity (Herfindahl-Hirschman) & $-57,863$ & 15,648 & -3.70 & $0.0003 * *$ & $0.0015^{* *}$ \\
South & 1,477 & 2,590 & 0.57 & 0.5690 & 0.4134 \\
Midwest & 4,973 & 4,004 & 1.24 & 0.2153 & 0.1174 \\
West & 9,580 & 3,324 & 2.88 & $0.0043 * *$ & $0.0259 *$ \\
Dependent Variable: Employment Change, $1987-1997$. & & & \\
Observations & 275 & & F Stat. & & 73.00 \\
$\mathrm{R}^{2}$ & 0.6204 & & F Prob. & & \\
Adjusted R $^{2}$ & 0.6119 & White Prob. & 0.4040 \\
\hline
\end{tabular}

* Significant at the $5 \%$ confidence level. ** Significant at the $1 \%$ confidence level. 


\section{REFERENCES}

Acs, Z. J., and C. Armington. 2004a. The impact of geographic differences in human capital on service firm formation rates. Journal of Urban Economics, 56 (2): 244-278.

Acs, Z. J., and C. Armington. 2004b. Employment growth and entrepreneurial activity in cities. Regional Studies, 38 (8): 911-927.

Acs, Z. J., and D. B. Audretsch. 1990. Innovation and Small Firms. Cambridge, Massachusetts: MIT Press.

Acs, Z. J., R. Morck, and B. Yeung. 1999. Productivity growth and firm size distribution. In Z. J. Acs, B. Carlsson, and C. Karlsson (eds.), Entrepreneurship, Small and Medium-Sized Enterprises and the Macroeconomy: 367-396. Cambridge, United Kingdom: Cambridge University Press.

Amato, L. 1995. The choice of structure measure in industrial economics. Quarterly Journal of Business and Economics, 34 (2): 39-52.

Amato, L., and R. P. Wilder. 1995. Alternative profitability measures and tests of the structureperformance relationship. Review of Industrial Organization, 10 (1): 21-31.

Andersson, R., J. M. Quigley, and M. Wilhelmsson. 2005. Agglomeration and the spatial distribution of creativity. Papers in Regional Science, 84 (3): 446-464.

Armington, C., and Z. J. Acs. 2002. The determinants of regional variation in new firm formation. Regional Studies, 36 (1): 33-45.

Attaran, M., and M. M. Saghafi. 1988. Concentration trends and profitability in the US manufacturing sector: 1970-84. Applied Economics, 20 (11): 1497-1510.

Audretsch, D. B. 1995. Innovation and Industry Evolution. Cambridge, Massachusetts: MIT Press.

Audretsch, D. B. 2003. Innovation and spatial externalities. International Regional Science Review, 26 (2): 167-174.

Audretsch, D. B., and D. Dohse. 2007. Location: a neglected determinant of firm growth. Review of World Economics, 143 (1): 79-107.

Audretsch, D. B., L. Klomp, E. Santarelli, and R. Thurik. 2004. Gibrat's Law: are the services different? Review of Industrial Organization, 24 (3): 301-324.

Azzam, A. M., D. I. Rosenbaum, and A. Weliwita. 1996. Is there more than one critical concentration ratio? An empirical test for the Portland cement industry. Applied Economics, 28 (6): 673-678.

Barrios, S., L. Bertinelli, and E. Strobl. 2006. Geographic concentration and establishment scale: an extension using panel data. Journal of Regional Science, 46 (4): 733-746.

Begovic, B. 1992. Industrial diversification and city size: the case of Yugoslavia. Urban Studies, 29 (1): 77-88.

Bergman, E. M. 2002. Sustainability of Clusters: Ten Dos and Don'ts. Presented at the FortyFirst Western Regional Science Association Annual Meeting: Monterey, California.

Bhattacharya, M., and H. Bloch. 2004. Determinants of innovation. Small Business Economics, 22 (2): 155-162.

Blair, J. P. 1975. Industrial decline, vertical integration, and geographic concentration. Growth and Change, 6 (3): 34-37.

Blair, J. P. 1978. Establishment size, market organization, and interindustry linkages. Growth and Change, 9 (4): 42-47. 
Bostic, R. W., J. S. Gans, and S. Stern. 1997. Urban productivity and factor growth in the late nineteenth century. Journal of Urban Economics, 41 (1): 38-55.

Bottazzi, G., E. Cefis, G. Dosi, and A. Secchi. 2007. Invariances and diversities in the patterns of industrial evolution: some evidence from Italian manufacturing industries. Small Business Economics, 29 (1-2): 137-159.

Brewer, H. L. 1985. Measures of diversification: predictors of regional economic instability. Journal of Regional Science, 25 (3): 463-470.

Capello, R. 2002. Spatial and sectoral characteristics of relational capital in innovation activity. European Planning Studies, 10 (2): 177-200.

Carlino, G. A. 1987. Comparisons of agglomeration: or what Chinitz really said: a reply. Urban Studies, 24 (1): 75-76.

Carree, M., and R. Thurik. 1999. Industrial structure and economic growth. In D. B. Audretsch, and R. Thurik (eds.), Innovation, Industry Evolution, and Employment: 86-110. Cambridge, United Kingdom: Cambridge University Press.

Caves, R. E. 1998. Industrial organization and new findings on the turnover and mobility of firms. Journal of Economic Literature, 36 (4): 1947-1982.

Caves, R. E., and D. R. Barton. 1990. Efficiency in U.S. manufacturing industries. Cambridge, Massachusetts: MIT Press.

Chen, H.-P. 2002. Urban externalities and city growth in Taiwan. Annals of Regional Science, 36 (4): 531-550.

Chevassus-Lozza, E., and D. Galliano. 2003. Local spillovers, firm organization and export behaviour: evidence from the French food industry. Regional Studies, 37 (2): 147-158.

Chinitz, B. 1961. Contrasts in agglomeration: New York and Pittsburgh. The American Economic Review, 51 (2): 279-289.

Cohen, W. M., and R. C. Levin. 1989. Empirical studies of innovation and market structure. In R. Schmalensee, and R. D. Willig (eds.), Handbook of Industrial Organization: 10591107. Amsterdam, Netherlands: Elsevier.

Combes, P.-P. 2000. Economic structure and local growth: France, 1984-1993. Journal of Urban Economics, 47 (3): 329-355.

Conroy, M. E. 1975. Regional Economic Diversification. New York, New York: Praeger Publishers.

Cool, K., and J. Henderson. 1998. Power and firm profitability in supply chains: French manufacturing industry in 1993. Strategic Management Journal, 19 (10): 909-926.

Cortes, B. S. 1998. Trends in industrial concentration in Japan, 1983-92. International Review of Applied Economics, 12 (2): 271-281.

Crozet, M., T. Mayer, and J.-L. Mucchielli. 2004. How do firms agglomerate? A study of FDI in France. Regional Science and Urban Economics, 34 (1): 27-54.

Davies, S. W., and P. A. Geroski. 1997. Changes in concentration, turbulence, and the dynamics of market shares. The Review of Economics and Statistics, 79 (3): 383-391.

Davis, S. J., J. C. Haltiwanger, and S. Schuh. 1996. Job Creation and Destruction. Cambridge, MA: MIT Press.

Desmet, K., and M. Fafchamps. 2005. Changes in the spatial concentration of employment across US counties: a sectoral analysis 1972-2000. Journal of Economic Geography, 5 (3): 261-284.

Dissart, J. C. 2003. Regional economic diversity and regional economic stability: research results and agenda. International Regional Science Review, 26 (4): 423-446. 
Drucker, J. 2007. Regional dominance and industrial success: a productivity-based analysis. Doctoral Dissertation, Department of City and Regional Planning, University of North Carolina: Chapel Hill, North Carolina.

Drucker, J., and E. J. Feser. 2007. Regional industrial dominance, agglomeration economies, and manufacturing plant productivity. Working Paper CES 07-31: Center for Economic Studies, United States Census Bureau. Available at http://www.ces.census.gov/index.php/ces/1.00/cespapers?down_key=101804 (accessed January 13, 2008).

Evans, A. W. 1986. Comparisons of agglomeration: or what Chinitz really said. Urban Studies, 23 (5): 387-389.

Feldman, M. P., and D. B. Audretsch. 1999. Innovation in cities: science-based diversity, specialization, and localized competition. European Economic Review, 43 (2): 409-429.

Feser, E. J. 2001. A flexible test for agglomeration economies in two US manufacturing industries. Regional Science and Urban Economics, 31 (1): 1-19.

Flammang, R. A. 1990. Development and growth revisited. Review of Regional Studies, 20: 49-55.

Fourie, F. C. v. N., and A. Smith. 1998. The concentration-profits stalemate I: causality and interpretation problems. South African Journal of Economics, 66 (4): 559-583.

Fourie, F. C. v. N., and A. Smith. 1999. The concentration-profits stalemate II: ideological rifts and methodological stress. South African Journal of Economics, 67 (1): 66-95.

Friedman, J. J. 1995. The effects of industrial structure and resources under the distribution of fast-growing small firms among US urbanised areas. Urban Studies, 32 (6): 863-884.

Fritsch, M., and O. Falck. 2007. New business formation by industry over space and time: a multidimensional analysis. Regional Studies, 41 (2): 157-172.

Fritsch, M., and R. Lukas. 1999. Innovation, cooperation, and the region. In D. B. Audretsch, and R. Thurik (eds.), Innovation, Industry Evolution, and Employment: 157-181. Cambridge, United Kingdom: Cambridge University Press.

Fritsch, M., and M. Meschede. 2001. Product innovation, process innovation, and size. Review of Industrial Organization, 19 (3): 335-350.

Gabe, T. M. 2003. Local industry agglomeration and new business activity. Growth and Change, 34 (1): 17-39.

Garcia-Mila, T., and T. J. McGuire. 1993. Industrial mix as a factor in the growth and variability of states' economies. Regional Science and Urban Economics, 23 (6): 731748.

Glaeser, E. L., H. D. Kallal, J. A. Scheinkman, and A. Schleifer. 1992. Growth in cities. Journal of Political Economy, 100 (6): 1126-1152.

Golan, A., G. Judge, and J. M. Perloff. 1996. Estimating the size distribution of firms using government summary statistics. The Journal of Industrial Economics, 44 (1): 69-80.

Gopinath, M., D. Pick, and Y. Li. 2004. An empirical analysis of productivity growth and industrial concentration in US manufacturing. Applied Economics, 36 (1): 1-17.

Gort, M., and N. Sung. 1999. Competition and productivity growth: the case of the U.S. telephone industry. Economic Inquiry, 37 (4): 678-691.

Gumbau-Albert, M., and J. Maudos. 2002. The determinants of efficiency: the case of the Spanish industry. Applied Economics, 34 (15): 1941-1948.

Hanson, G. H. 2001. Scale economies and the geographic concentration of industry. Journal of Economic Geography, 1 (3): 255-276. 
Harrison, B., M. R. Kelley, and J. Gant. 1996. Innovative firm behavior and local milieu: exploring the intersection of agglomeration, firm effects, and technological change. Economic Geography, 72 (3): 233-258.

Hay, D. A., and D. J. Morris. 1991. Industrial Economics and Organization: Theory and Evidence. Oxford, United Kingdom: Oxford University Press.

Henderson, J. V. 1986. Efficiency of resource usage and city size. Journal of Urban Economics, 19 (1): 47-70.

Henderson, J. V. 1997. Externalities and industrial development. Journal of Urban Economics, 42 (3): 449-470.

Henderson, J. V. 2003. Marshall's scale economies. Journal of Urban Economics, 53 (1): 128.

Henderson, J. V., A. Kuncoro, and M. A. Turner. 1995. Industrial development in cities. Journal of Political Economy, 103 (5): 1067-1090.

Hewings, G. J. D., M. Sonis, J. Guo, P. R. Israilevich, and G. R. Schindler. 1998. The hollowing-out process in the Chicago economy, 1975-2011. Geographical Analysis, 30 (3): 217-233.

Holmes, T. J. 1999. Localization of industry and vertical disintegration. The Review of Economics and Statistics, 81 (2): 314-325.

Holmes, T. J., and J. J. Stevens. 2002. Geographic concentration and establishment scale. The Review of Economics and Statistics, 84 (4): 682-690.

Hunt, G. L., and T. J. Sheesley. 1994. Specification and econometric improvements in regional portfolio diversification analysis. Journal of Regional Science, 34 (2): 217-235.

Ijiri, Y., and H. A. Simon. 1977. Skew Distributions and the Sizes of Business Firms. Amsterdam, Netherlands: North-Holland Publishing.

Izraeli, O., and K. J. Murphy. 2003. The effect of industrial diversity on state unemployment rate and per capita income. Annals of Regional Science, 37 (1): 1-14.

Kambhampati, U. S. 1998. Market structure dynamics in Indian industry. Bulletin of Economic Research, 50 (2): 133-153.

Kambhampati, U. S., and P. McCann. 2007. Regional performance and characteristics of Indian manufacturing industry. Regional Studies, 41 (3): 281-294.

Keeble, D., and S. Walker. 1994. New firms, small firms and dead firms: spatial patterns and determinants in the United Kingdom. Regional Studies, 28 (4): 429-442.

Kelley, M. R., and S. Helper. 1999. Firm size and capabilities, regional agglomeration, and the adoption of new technology. Economics of Innovation and New Technology, 8 (1-2): 79103.

Kelly, T., and M. L. Gosman. 2000. Increased buyer concentration and its effects on profitability in the manufacturing sector. Review of Industrial Organization, 17 (1): 4159.

Kim, S. 1995. Expansion of markets and the geographic distribution of economic activities: the trends in U.S. regional manufacturing structure, 1860-1987. The Quarterly Journal of Economics, 110 (4): 881-908.

Lafourcade, M., and G. Mion. 2007. Concentration, agglomeration and the size of plants. Regional Science and Urban Economics, 37 (1): 46-68.

Lee, S. Y., R. Florida, and Z. J. Acs. 2004. Creativity and entrepreneurship: a regional analysis of new firm formation. Regional Studies, 38 (8): 879-891. 
Loveridge, S., and D. Nizalov. 2007. Operationalizing the entrepreneurial pipeline theory: an empirical assessment of the optimal size distribution of local firms. Economic Development Quarterly, 21 (3): 244-262.

Malizia, E. E., and S. Ke. 1993. The influence of economic diversity on unemployment and stability. Journal of Regional Science, 33 (2): 221-235.

Martin, S. 1979. Advertising, concentration, and profitability: the simultaneity problem. The Bell Journal of Economics, 10 (2): 639-647.

McGuckin, R. H. 1990. Longitudinal Economic Data at the Census Bureau: A New Database Yields Fresh Insights On Some Old Issues. Working Paper CES-WP-90-1. Available at http://www.ces.census.gov/index.php/ces/1.00/cespapers?down_key=100131 (accessed September 29, 2007).

McGuckin, R. H., and G. A. Pascoe, Jr. 1988. The Longitudinal Research Database (LRD): Status and Research Possibilities. Working Paper CES-WP-88-2. Available at http://www.ces.census.gov/index.php/ces/1.00/cespapers?down_key=100107 (accessed September 29, 2007).

Melville, N., V. Gurbaxani, and K. Kraemer. 2007. The productivity impact of information technology across competitive regimes: the role of industry concentration and dynamism. Decision Support Systems, 43 (1): 229-242.

Mizuno, K., F. Mizutani, and N. Nakayama. 2006. Industrial diversity and metropolitan unemployment rate. Annals of Regional Science, 40 (1): 157-172.

Moomaw, R. L. 1986. Have changes in localization economies been responsible for declining productivity advantages in large cities? Journal of Regional Science, 26 (1): 193-2.

Needham, D. 1978. The Economics of Industrial Structure, Conduct, and Performance. New York, New York: St. Martin's Press.

Nickell, S. J. 1996. Competition and corporate performance. Journal of Political Economy, 104 (4): 724-746.

Nickell, S. J., D. Nicolitsas, and N. Dryden. 1997. What makes firms perform well? European Economic Review, 41 (3-5): 783-796.

Norton, R. D. 1992. Agglomeration and competitiveness: from Marshall to Chinitz. Urban Studies, 29 (2): 155-170.

Nystrom, K. 2007. An industry disaggregated analysis of the determinants of regional entry and exit. Annals of Regional Science, 41 (4): 877-896.

Okuyama, Y., M. Sonis, and G. J. D. Hewings. 2006. Typology of structural change in a regional economy: a temporal inverse analysis. Economic Systems Research, 18 (2): 133-153.

Porter, M. E. 1990. The Competitive Advantage of Nations. New York, New York: MacMillan.

Powell, T. C. 2003. Varieties of competitive parity. Strategic Management Journal, 24 (1): 61-86.

Powell, T. C., and C. J. Lloyd. 2005. Toward a general theory of competitive dominance: comments and extensions on Powell (2003). Strategic Management Journal, 26 (4): 385-394.

Pryor, F. L. 2001. New trends in U.S. industrial concentration. Review of Industrial Organization, 18 (3): 301-326.

Quigley, J. M. 1998. Urban diversity and economic growth. Journal of Economic Perspectives, $12(2): 127-138$. 
Robinson, K. C. 1999. An examination of the influence of industry structure on eight alternative measures of new venture performance for high potential independent new ventures. Journal of Business Venturing, 14 (2): 165-187.

Robinson, K. C., and P. P. McDougall. 1998. The impact of alternative operationalizations of industry structural elements on measures of performance for entrepreneurial manufacturing ventures. Strategic Management Journal, 19 (11): 1079-1100.

Rogers, M. 2004. Networks, firm size and innovation. Small Business Economics, 22 (2): 141153.

Rosenthal, S. S., and W. S. Strange. 2003. Geography, industrial organization, and agglomeration. The Review of Economics and Statistics, 85 (2): 377-393.

Rosenthal, S. S., and W. S. Strange. 2004. Evidence on the Nature and Sources of Agglomeration Economies. In J. V. Henderson, and J.-F. Thisse (eds.), Handbook of Urban and Regional Economics, Vol. 4: 2119-2171. Amsterdam, Netherlands: Elsevier.

Scherer, F. M. 1967. Market structure and the employment of scientists and engineers. The American Economic Review, 57 (3): 524-531.

Scherer, F. M. 1980. Industrial Market Structure and Economic Performance. Second Ed. Boston, Massachusetts: Houghton Mifflin.

Schmalensee, R. 1989. Inter-industry studies of structure and performance. In R. Schmalensee, and R. D. Willig (eds.), Handbook of Industrial Organization: 951-1009. Amsterdam, Netherlands: Elsevier.

Shaffer, S. 2002. Firm size and economic growth. Economics Letters, 76 (2): 195-203.

Shaffer, S. 2006a. Establishment size by sector and county-level economic growth. Small Business Economics, 26 (2): 145-154.

Shaffer, S. 2006b. Establishment size and local employment growth. Small Business Economics, 26 (5): 439-454.

Shefer, D. 1973. Localization economies in SMSAs: a production function analysis. Journal of Regional Science, 13 (1): 55-64.

Shepherd, W. G. 1982. Causes of increased competition in the U.S. economy, 1939-1980. The Review of Economics and Statistics, 64 (4): 613-626.

Sutaria, V., and D. A. Hicks. 2004. New firm formation: dynamics and determinants. Annals of Regional Science, 38 (2): 241-262.

Sutton, J. 1997. Gibrat's legacy. Journal of Economic Literature, 35 (1): 40-59.

Thompson, W. R. 1974. Employment and Industrial Development Opportunities in the Inner City: The Inner City Labor Markets. Storrs, Connecticut: Center for Real Estate and Urban Economic Studies, School of Business Administration, University of Connecticut.

Trendle, B. 2006. Regional economic instability: the role of industrial diversification and spatial spillovers. Annals of Regional Science, 40 (4): 767-778.

United States Census Bureau. 2002. Metropolitan Areas and Components, 1999. Available at http:/www.census.gov/population/estimates/metro-city/99mfips.txt (accessed September 29, 2007).

United States Census Bureau. n.d.-a. County Business Patterns. Available at http:/censtats.census.gov/cbpnaic/cbpnaic.shtml, http://censtats.census.gov/cbpsic/cbpsic.shtml, and http://fisher.lib.virginia.edu/collections/stats/cbp/national.html (accessed May 25, 2008). 
United States Census Bureau. n.d.-b. Census Regions and Divisions of the United States. Available at www.census.gov/geo/www/us_regdiv.pdf (accessed May 26, 2008).

Vossen, R. W. 1999. Market power, industrial concentration and innovative activity. Review of Industrial Organization, 15 (4): 367-378.

Wagner, J. E., and S. C. Deller. 1998. Measuring the effects of economic diversity on growth and stability. Land Economics, 74 (4): 541-556.

Wheeler, C. H. 2006. Productivity and the geographic concentration of industry: the role of plant scale. Regional Science and Urban Economics, 36 (3): 313-330. 